\title{
1 Dense shelf water formation and brine-driven circulation \\ in the Adélie and George V Land region
}

\section{Abstract}

9 The formation and outflow of Dense Shelf Water (DSW) from the Adélie and

\author{
Kazuya Kusahara ${ }^{\mathrm{a}, *}$, Hiroyasu Hasumi ${ }^{\mathrm{a}}$, Guy D. Williams ${ }^{\mathrm{b}}$ \\ ${ }^{a}$ Atmosphere and Ocean Research Institute, The University of Tokyo, 5-1-5, \\ Kashiwanoha, Kashiwa-shi, Chiba, 277-8568, Japan. \\ LOCEAN, UMR 7159 CNRS/UPMC/IRD/MNHN, Université Pierre et Marie Curie, 4 \\ place Jussieu, Paris, France
}


25 the Mertz Depression. Assuming a critical density of $27.88(27.80) \mathrm{kg} \mathrm{m}^{-3}$
${ }_{26}$ for outflowing DSW, the annual mean export from the Adélie and Mertz Sills
${ }_{27}$ are 0.21 (0.37) Sv and $0.12(0.32) \mathrm{Sv}$, respectively. The model clearly shows
28 a dual-system for DSW formation and export from the Adélie and Mertz De-
29 pressions, consistent with recent observational analysis over the continental
30 slope and rise.
31 Keywords: Dense Shelf Water, brine rejection, Adélie and Mertz
32 Depressions 


\section{Introduction}

Antarctic Bottom Water (AABW) is the cold, dense water mass in the abyssal layer of the the World Ocean that is critical to the global climate system, composing the lower limb of the global thermohaline circulation in the southern hemisphere (Orsi et al., 1999). AABW is produced in key source regions of the Antarctic margin by the overflows of Dense Shelf Water (DSW) formed on the continental shelf by regionally varying combinations of coastal polynyas and ocean-ice shelf interaction. In the Weddell Sea and eastern sector of the Ross Sea (see Fig. 1a), the cooling and freshening influence of melting beneath the large continental ice shelves in these regions is integral to the export of DSW for AABW production (Schlosser et al., 1990; Foldvik et al., 2004; Smethie Jr. and Jacobs, 2005; Orsi and Wiederwohl, 2009). In other areas removed from the continental ice shelves the primary mechanism for DSW formation is brine-rejection from enhanced sea-ice production in coastal polynyas (western Ross Sea, East Antarctica). AABW is typically formed by overflows of DSW mixing with Antarctic Surface Water (AASW) and modified Circumpolar Deep Water (mCDW), as it is transported downslope to the abyssal layer.

In the Australian-Antarctic Basin sector of East Antarctica, the dominant source region is Adélie and George V Land (AGVL) continental shelf (Gordon and Tchernia, 1972; Rintoul, 1998), in particular the coastal polynya regime over the Adélie and Mertz Depressions west/east of the Mertz Glacier Tongue (MGT) (Williams et al., 2010). These depressions (sometimes referred to as troughs) are suitable for the formation and export of DSW for the following reasons. Firstly, there are persistent coastal polynyas in winter with high 
sea ice production (Tamura et al., 2008; Williams et al., 2010). Secondly, the depressions provide storage for the accumulation of salinity from brinerejection and insulate newly-formed DSW under the coastal polynya from lateral mixing with the mCDW that penetrates southwards across the shelf break. Thirdly, both regions have bathymetric export pathways through sills in the shelf break.

Direct sea-ice/oceanic measurements in coastal polynyas around Antarctica are temporally and spatially limited due to geographical and climatic difficulties. The first wintertime oceanographic observations of the Adélie Depression during the 'Mertz Polynya Experiment' (July-September 1999) described the water mass properties and general circulation, confirming the formation of DSW and provided an estimate of the corresponding sea-ice growth rates (Bindoff et al., 2001; Williams and Bindoff, 2003). Williams et al. (2008) described the seasonal formation and export of DSW from moored instruments in the Adélie Depression and Adélie Sill between 19982000. Williams et al. (2010) extended this analysis to moored instruments and ship-based measurements from the austral summer of 2001 and spring of 2004 on the upper continental slope and lower continental rise, describing a dual-system of DSW export from Adélie (primary) and Mertz (secondary) Depressions.

Numerical modeling, that can reproduce the observed water masses and circulation, offers to improve our understanding of the processes in the AGVL region. To achieve this, suitable models must explicitly resolve coastal polynyas, whose typical horizontal scale is from a few to $100 \mathrm{~km}$, and the associated physical processes therein. Previous modeling in the Antarctic and Southern 
Ocean region has not employed such high resolution, with a few exceptions 84 (Marsland et al., 2004, 2007; Kusahara et al., 2010). Moreover, to resolve the 85 bottom topography of the coastal region (e.g. sill, depression, shelf break, 86 etc.) which strongly controls water mass exchange into and out of the conti87 nental shelf region, a spatial resolution of a few kilometers is required. The 88 purpose of this study is to investigate the formation and outflow of DSW 89 and the seasonal variation of the ocean circulation in the AGVL region us90 ing an ice-ocean model of regionally high resolution. Section 2 describes the 91 ice-ocean model. In section 3 , we validate the model results against direct 92 observations in the Adélie Depression. In section 4, we describe the modeled 93 ocean circulation and water mass formation in the AGVL region. In section ${ }_{94} 5$, we examine the mechanisms of ocean circulation in the Adélie Depression 95 by idealized numerical experiments. Summary and discussion are presented 96 in section 6 . 


\section{Ice-ocean model}

We use the ice-ocean model COCO (Hasumi, 2006). The sea ice model adopts a two-category thickness representation (Hibler, 1979). Its thermodynamics is based on Bitz and Lipscomb (1999), with one layer for ice and a noheat-capacity layer for snow. Prognostic equations for momentum, mass and concentration are taken from Mellor and Kantha (1989). Internal ice stress is formulated by the elastic-viscous-plastic rheology (Hunke and Dukowicz, 1997). The model domain is global (Fig. 1a for the Southern Ocean). To achieve high resolution in the focal region (Fig. 1b), two singular points of the horizontal curvilinear coordinate are placed on East Antarctica $\left(70^{\circ} \mathrm{E}\right.$ $70.5^{\circ} \mathrm{S}$ and $\left.143^{\circ} \mathrm{E} 68^{\circ} \mathrm{S}\right)$. The horizontal grid size over the coastal area in East Antarctica is between a few kilometers and $15 \mathrm{~km}$ and that in the Adélie and Mertz Depressions is within a few kilometers (Fig. 1b). The vertical coordinate system of the ocean model is a hybrid of $\sigma$ (normalized depth) and z. There are 69 vertical levels: $\sigma$ coordinate is applied to the five uppermost levels between the free surface and $50 \mathrm{~m}$ below the mean surface level, and the $\mathrm{z}$ coordinate is applied below. The vertical grid spacing in the $\mathrm{z}$ coordinate region is $50 \mathrm{~m}$ (29 grids) and $100 \mathrm{~m}$ (35 grids) above and below $1500 \mathrm{~m}$, respectively. A partial step representation is adopted for the bottom topography (Adcroft et al., 1997).

The ocean model includes a uniformly third order polynomial interpolation algorithm for tracer advection (Leonard et al., 1993), isopycnal diffusion, isopycnal layer thickness diffusion (Gent et al., 1995), and a surface mixed layer parameterization based on turbulence closure (Noh and Kim, 1999). The isopycnal diffusion coefficient is $1.0 \times 10^{2} \mathrm{~m}^{2} \mathrm{~s}^{-1}$ and the thickness dif- 
fusion coefficient is $1.0 \mathrm{~m}^{2} \mathrm{~s}^{-1}$. The background vertical diffusion coefficient is $1.3 \times 10^{-5} \mathrm{~m}^{2} \mathrm{~s}^{-1}$ at the surface and gradually increases with depth up to $2.9 \times 10^{-4} \mathrm{~m}^{2} \mathrm{~s}^{-1}$ (case III of Tsujino et al. (2000)). The background vertical viscosity coefficient is $1.0 \times 10^{-4} \mathrm{~m}^{2} \mathrm{~s}^{-1}$. Horizontal eddy viscosity is parameterized by a Laplacian form, and its coefficient spatially varies so as to resolve the Munk layer. The bottom friction is parameterized by a simple quadratic law with a constant drag coefficient of $1.3 \times 10^{-3}$. Convection is represented by a simple convective adjustment scheme.

The ice-ocean drag coefficient is $3.0 \times 10^{-3}$, and the associated turning angle is $-10^{\circ}$ relative to the direction of the uppermost layer velocity in the ocean model. To parameterize subgrid-scale leads, the maximum sea ice concentration is set to 0.98 . Sea ice salinity is fixed at 5 psu. In the framework of a two-category sea ice model, the open/newly-formed ice area and the consolidated sea ice area coexist in one grid, and a minimum thickness for the consolidated sea ice (demarcation thickness) must be specified. A demarcation thickness of $10 \mathrm{~cm}$ is used in this study. It should be noted that sea ice production is a key factor controlling the ocean circulation in an Antarctic coastal polynya system, and that the ice model used in this study successfully reproduces the sub-regional locations of the coastal polynyas and high sea ice production around the AGVL region (Kusahara et al., 2010).

The model bathymetry, as shown in Fig. 1, is derived from GEBCO (IOC, IHO, BODC, 1994) and the data around the Adélie Sill $\left(142.0^{\circ} \mathrm{E}-145.0^{\circ} \mathrm{E}\right.$, $66.2^{\circ} \mathrm{S}-65.7^{\circ} \mathrm{S}$ ) is updated by shiptrack data prior to 2002 (Porter-Smith, 2003). To realistically reproduce the horizontal topography, the coastline around Antarctica incorporates the summertime ice shelf and iceberg tongue 
edges identified by the MODIS Mosaic of Antarctica Image Map (Haran et al., 2005). Observations indicate that coastal polynyas are formed in the downwind/downstream or 'lee' side of grounded icebergs and floating ice tongues, as well as in continental bays (Massom et al., 1998). To incorporate the blocking effect of sea ice advection by such grounded icebergs into the model, we set the sea ice velocity to zero at the corresponding grid points (Kusahara et al., 2010). In reality, there are spatial gaps among grounded icebergs, which allow sea water to pass through. Therefore in the model, oceanic flows are permitted below the grid points of grounded icebergs. In this study grounded icebergs are placed in the northern region of the Mertz Glacier tongue (sometimes referred to as 'the dagger'), along $149^{\circ} \mathrm{E}$, and along $149.75^{\circ} \mathrm{E}$ (Fig. 1b).

The surface boundary conditions for the model include: surface wind, air temperature, specific humidity, downward shortwave, downward longwave, fresh water flux, and sea level air pressure. Daily data are utilized for all components. To calculate the wind stress and sensible and latent heat fluxes, we use the bulk formula of Kara (2000). When the surface air temperature is below $0^{\circ} \mathrm{C}$, precipitation is treated as snow. Outside of the area within 100 $\mathrm{km}$ from the coast of East Antarctica between $50^{\circ} \mathrm{E}$ and $160^{\circ} \mathrm{E}$, sea surface salinity is restored to the monthly mean climatology with a 10 day damping timescale to suppress the bias towards overly deep convection in the offshore region. In the northern hemisphere, temperature and salinity are restored to the monthly mean climatology (Steele et al., 2001) throughout the water column. We perform an 18-year integration with the surface air climatology of Röske (2006) to obtain a quasi-steady state and continue the integration for 
172 three years by switching from the forcing data to 1979 of the NCEP/NCAR 173 reanalysis (Kalnay, 1996) to avoid an initial shock to modeled system. After 174 initialisation, we perform a simulation from 1979 to 2008. The model results 175 for the thirty years 1979 - 2008 are utilized for the following analysis. In 176 some of the analyses for the ocean, we use monthly climatologies averaged 177 over the above period. 


\section{Validation of model results against observations in the Adélie Depression}

Here we validate the model results against hydrographic and mooring observations in the Adélie Depression (Williams and Bindoff, 2003; Williams et al., 2008). The wintertime hydrographic sections ('Shelf-Break' and 'Loop' sections of Williams and Bindoff, 2003) are shown in Fig. 2a, together with the areas over which the modeling results are averaged for comparison with the mooring data (Williams et al., 2008). Major place names and small scale seamounts over the Mertz Bank (mb1, mb2, mb3, and mb4) are also labeled in Fig. 2a.

For the convenience of quantitative comparison, we use potential density $\left(\sigma_{\theta}\right)$ of $27.88 \mathrm{~kg} \mathrm{~m}^{-3}$ as a lower limit of DSW in the Adélie Depression for two reasons. Firstly, this potential density corresponds to the lower limit of modeled DSW when DSW is defined by a dense water which outflows from the Adélie Depression and whose outflow ceases in summer. Secondly, a number of previous observational studies in the Adélie Depression (Bindoff et al., 2001; Williams and Bindoff, 2003; Williams et al., 2008) suggest this is a conservative estimate of the minimum potential density for exported DSW to produce AABW (hereafter referred to as the critical density). While a detailed discussion about the best water mass definition of DSW is beyond the scope of this paper, we note that defining the critical density of DSW, i.e. the density at which there is sufficient negative buoyancy for downslope AABW production to begin, is problematic due to its dependence on the spatiotemporal variability of the ambient offshore density field (Williams et al., 2010). It is also problematic for models to use rigid water mass definitions 
determined from observations when systematic biases are present.

We also use neutral density $\left(\gamma^{n}\right.$, Jackett and McDougall, 1997), which is frequently used for defining water masses in the Southern Ocean. Neutral density surfaces of 28.00 and $28.27 \mathrm{~kg} \mathrm{~m}^{-3}$ correspond to the highest density (deeper limit) of AASW and the lowest density (shallower limit) of AABW, respectively (Orsi et al., 1999; Bindoff et al., 2000; Orsi and Wiederwohl, 2009). The layer between these two neutral density surfaces is defined as mCDW. Note that in the potential temperature-salinity space the potential density surface of $27.80 \mathrm{~kg} \mathrm{~m}^{-3}$ roughly traces the neutral density surface of $28.27 \mathrm{~kg} \mathrm{~m}^{-3}$ for cold temperatures.

\subsection{Shelf-Break section}

The modeled vertical profiles of potential temperature, salinity, and potential density along the Shelf-Break section in August are shown in Figure 3. Near-freezing temperatures are found in the surface 50-m-thick layer and the bottom 400-m-thick layer in the Adélie Depression (Fig. 3a). The maximum potential temperature is at intermediate depths (between 100 and $300 \mathrm{~m}$ ) over the whole section. The warmest intrusion, with potential temperature around $-0.8^{\circ} \mathrm{C}$, is found between stations 59 and 60 (to the north of mb2) at depths around $300 \mathrm{~m}$.

The near-freezing water at the base of the Adélie Depression has high salinity, up to $34.7 \mathrm{psu}$ (Fig. 3b). There is another salinity maximum near the bottom between stations 61 and 63 whose value (34.6 psu) is slightly lower than in the Adélie Depression. The water from the surface to $300 \mathrm{~m}$ is fresher, with a minimum value of about 34.35 psu centered between stations 59 and 60. Isohaline contours are slanted in the eastern half of the Shelf- 
Break section, and they outcrop between stations 62 and 63. The potential density has a similar pattern to salinity, as the temperature dependence of density at this temperature is weak.

The modeled features of potential temperature and salinity are broadly consistent with the observational results (Williams and Bindoff, 2003, colored circles in Fig. 3). However, there are three notable differences. Firstly, the modeled intrusion at 200-300 m depths is wider and warmer than the observed one (Figs. 3a and 4a-b). Secondly, the modeled salinity in the surface 150-m-thick layer and the corresponding potential density are lower than the observed one (Figs. 3b and 4a-b). Finally, the modeled salinity and potential density at depths from 200 to $400 \mathrm{~m}$ are higher than observed. These observed properties are outside the standard deviation of the interannual variability in the model, implying that there are systematic biases in the model.

A strong vertical velocity shear is found just to the east of station 57, with a southeastward surface flow of lighter waters and a northwestward bottom flow of denser waters. The velocity shear is consistent with a potential density front which is formed over the southeastern flank of the Mertz Bank (Fig. 3c). There are four separate southward flows across this section between stations 59 and 63: the first between stations 59 and 60, the second to the east of station 60 (over the western flank of the northward protruding topography from mb3), the third to the east of station 61 , and the fourth between stations 62 and 63 (over the western flank of mb4). These flows have a vertically coherent structure with the maximum velocity near the surface. The second and fourth flows have relatively large velocity from $100 \mathrm{~m}$ depth 
to the bottom, suggesting that there is net inflow into the Adélie Depression.

The first and third flows are along topography (see horizontal velocity fields shown later).

Characterizing the water masses using density, the features along the Shelf-Break section are briefly summarized as follows. AASW of 100-200 m-thick flows into the Adélie Depression over the whole section across the shelf break. The water of mCDW, which is positioned below AASW, flows into the Adélie Depression along the strong density front formed over the southwestern flank of the Mertz Bank and bottom topography. The waters in the densest classes (DSW) have a bottom intensified structure and flow northwestward to the Adélie Sill.

\subsection{Loop section}

Figure 5 shows the modeled vertical profiles of potential temperature, salinity, and potential density along the Loop section in August. The Loop section consists of sections 1, 2, and 3 (Fig. 2a).

Potential temperature is a maximum of about $-1.4^{\circ} \mathrm{C}$ at around $300 \mathrm{~m}$ over the southwestern flank of the Mertz Bank (Figs. 4 and 5a). Waters of near-freezing temperatures are found at the surface over the whole section and over the full water columns in the coastal areas. The potential temperature maximum in the Loop section is linked with that of the mCDW inflow in the Shelf-Break section.

There are salinity and density fronts over the southwestern flank of the Mertz Bank (Fig. 5b and 5c), with fresher, less dense water in the surface layer around the boundary between sections 1 and 2. Higher salinity waters are found in the coastal areas of sections 1 and 3, indicating brine rejection 
from coastal polynyas. The position and slope of the $27.88 \mathrm{~kg} \mathrm{~m}^{-3}$ isopycnal are in reasonable agreement with observations (Williams and Bindoff, 2003). Again, there are some model biases as well as in the Shelf-Break section (Fig. $4 c-d)$.

In section 1 there is a southeastward surface flow and a northeastward bottom flow over the southwestern flank of the Mertz Bank, while there is a weak inflow into the interior of the Loop section over the whole of section 2 . In section 3, there is a southeastward flow at depths between the surface and 200 $\mathrm{m}$, which is directed towards the Mertz Glacier Tongue, and a northwestward inflow in the bottom layer. Once again characterizing the water masses by density, we find AASW and mCDW flowing towards the Mertz Glacier Tongue along the southwestern flank of the Mertz Bank and the densest shelf waters flowing northwestwards to the Adélie Sill.

Williams and Bindoff (2003) estimated the absolute velocity along the Loop section based on data from the shipboard ADCP and geostrophic shear from hydrography. The velocity normal to the section (Fig. 5) does not agree well with the observation (Fig. 11 of Williams and Bindoff, 2003). However, it should be noted that the observational estimate includes tides and short-term variability due to eddies. It is difficult to directly compare the climatological average of the modeled velocity with the observational estimate. Overall the good agreement of the tracer fields between the model and the observation indicates model's ability to reproduce the time-average velocity field. 


\subsection{Seasonal variation in the Adélie Depression and at the Adélie Sill}

Figure 6 shows the seasonal variations of potential density in the areas near the Mertz Glacier Tongue (A in Fig. 2a, hereafter referred to as the 'depression' region) and just south of the Adélie Sill (B in Fig. 2a, hereafter referred to as the 'sill' region). The seasonal variation of potential density in the Adélie Depression is closely linked to the sea ice production there, whose seasonal variation is displayed in Fig. 7 (see an area enclosed by dashed line in Fig. 2a, hereafter referred to as the 'control volume'). Sea ice production within $30 \mathrm{~km}$ from the coast accounts for about $60 \%$ of the total ice production in the Adélie Depression (Figs. 2b and 7).

In the depression region (Fig. 6a), a strong stratification forms near the sea surface in summer, which is then eroded in March due to sea ice production and the associated brine rejection. From July to August, when sea ice production reaches its maximum, deep convection occurs in the coastal area and the potential density over the whole water column increases. The potential density at the surface and bottom reaches a maximum in August and September, respectively. Subsequently, the surface layer starts restratify from December after the cessation of sea ice production.

The strong near-surface stratification in the sill region also begins to erode in March, as in the case of the depression region (Fig. 6b). Sea ice production is relatively smaller in this area, due to its distance from the coast (Figs. $2 \mathrm{~b}$ and 7). There is no deep convection increasing the potential density over the whole water column, but there is limited convection from April to May. At depths deeper than $200 \mathrm{~m}$, the potential density starts to increase in June and is a maximum in October. Subsequently, the potential density decreases 
gradually from November to April.

Figure $6 \mathrm{c}$ shows the seasonal variations at 425 and $575 \mathrm{~m}$ for the two regions, in both the model and the observations. The observed monthly values are calculated from the available mooring data in the period from April 1998 to April 1999 (Williams et al., 2008). In the model, potential density starts to increase in May at $425 \mathrm{~m}$ in both regions. Potential density in the sill region reaches a maximum in October, which is a month after the peak in the depression region, and the maximum value in the sill region is higher than in the depression region. These modeled features are similar to those observed (Williams et al., 2008).

The model reproduces the observed seasonal variations at the four mooring depth/locations in terms of the amplitude and phase. The modeled potential density, on the other hand, is biased toward higher density. The largest bias is found at the depth of $575 \mathrm{~m}$ in the depression region. There are several possible reasons for the model bias. Firstly, there is no interaction between ice shelves and the ocean in this model. Williams et al. (2008) showed the existence of Ice Shelf Water (ISW) at the depth of $587 \mathrm{~m}$ near the Mertz Glacier Tongue and described the classic 'ice-pump' mechanism by which the densest shelf water at the base of the Adélie Depression migrates to the grounding line at the back of the Mertz Glacier, ultimately producing colder, fresher Ice Shelf Water that re-enters the Adélie Depression at middepths in the southern half of the MGT that is intensified near Buchanan Bay. The lack of ISW in this model is consistent with the largest bias found at $575 \mathrm{~m}$ in the depression region. Secondly, no flow is permitted under the Mertz Glacier Tongue in the model. The water mass exchange under the 
Mertz Glacier Tongue from the Mertz Depression may influence the water mass properties in the Adélie Depression. The third is uncertainty in the forcing data set. Tamura et al. (2008) reported that the sea ice production estimated from the NCEP/NCAR reanalysis surface air data is larger by $26 \%$ than that esitimated from the ECMWF reanalysis. Since the current model is driven by the NCEP/NCAR reanalysis, it is likely that the current model tends to be biased toward larger DSW production. This model bias is an important consideration when estimating the formation of DSW based on water mass definitions derived from observations. 


\section{Circulation and water mass budget}

\subsection{Adélie Depression}

\subsubsection{Winter regime}

Sea ice production in the Adélie Depression starts in March, and the coastal areas exhibit active sea ice formation from May to September (Fig. 7). The potential density in the Adélie Depression reaches the maximum in September (Fig. 6). Isopycnal surfaces corresponding to $\gamma^{n}=28.00$ and $28.27 \mathrm{~kg} \mathrm{~m}^{-3}$ and $\sigma_{\theta}=27.88 \mathrm{~kg} \mathrm{~m}^{-3}$ are outcropped at the surface (Figs. $8 \mathrm{a}$ and 10a). In the surface layer (top $50 \mathrm{~m}$ ), there are flows across the shelf break toward the coastal areas which exhibit high sea ice production. In the subsurface $(125 \mathrm{~m})$ and middle $(275 \mathrm{~m})$ layers, there are three routes of southward flow across the shelf break into the Adélie Depression (Fig. 10a): to the west of mb1, between mb2 and mb3, and to the west of mb4. These southward flows merge into one stream over the southwestern flank of the Mertz Bank and the merged flow is directed to the Mertz Glacier Tongue (Fig. 8b and 8c). The potential temperature is a maximum in the subsurface and middle layers along this flow, which extends from the shelf break to the edge of the Mertz Glacier Tongue.

In the middle layer, there is a strong density front which runs parallel to the southwestern flank of the Mertz Bank. To the north of the density front there is a merged southeastward flow coming from shelf break (fig. 8b and 8c). An opposing flow exists to the south of the front in the middle and lower $(425 \mathrm{~m})$ layers, which flows from the Mertz Glacier Tongue to the Adélie Sill (Fig. 8c and 8d). The water as dense as $27.88 \mathrm{~kg} \mathrm{~m}^{-3}$ extends to the north of the Adélie Sill, indicating a pronounced outflow of DSW that 
has a bottom-intensified structure (Figs. 8c-d and 10a).

Along the density front, a warmer water mass, corresponding to AASW and $\mathrm{mCDW}$, intrudes across the shelf break in the middle layer (Fig. 8g). The potential temperature maximum in the intermediate depths of the ShelfBreak and Loop sections discussed in the previous section corresponds to this intrusion. The flow patterns in the formation periods of DSW, from June to August, are similar to Fig. 8, except that the density contrast and flow speed are smaller (not shown).

\subsubsection{Summer regime}

Sea ice production decreases rapidly in October and ceases in December (Fig. 7), the surface layer in the Adélie Depression becoming strongly stratified by February (Fig. 6). There is a surface-intensified clockwise (cyclonic) circulation trapped in the Adélie Depression (Fig. 9), as indicated by the dome of dense water at the center of the circulation in the middle and lower layers. In the surface and subsurface layers, fresher waters caused by sea ice melting exist in the coastal area, and a strong westward flow is formed along the coast. The coastal current flows out from the western end of the region in the surface layer and from the northern end in the subsurface and middle layers (Figs. 9a-c and 10). The intrusion of AASW and mCDW from the shelf break extends around the slope of the Adélie depression in a clockwise manner.

\subsubsection{Water mass budget}

Figure 11 shows the seasonal variation of the net transport across the boundaries of the control volume and across the Adélie Sill (along the north- 
ern end of the control volume west of $143.75^{\circ} \mathrm{E}$ ) in each $0.02 \mathrm{~kg} \mathrm{~m}^{-3}$ potential density bin. Throughout the year, there are inflows of relatively light waters into the control volume and outflows of relatively dense waters (Fig. 11e). The seasonal variation of the outflowing DSW across the Adélie Sill is almost the same as that across the northern end of the control volume. It indicates that the outflow of DSW predominantly occurs at the Adélie Sill. The outflow volume flux of DSW from the Adélie Sill reaches the maximum of 0.54 Sv in September and becomes zero in May. The annual mean DSW outflow from the Adélie Sill and from the whole Adélie Depression is $0.21 \mathrm{~Sv}$ and $0.26 \mathrm{~Sv}$, respectively. From June to December, the volume loss for the outflow of DSW is balanced by the inflow of less dense waters across the northern boundary. In this study, we use the cutoff potential density of $27.88 \mathrm{~kg} \mathrm{~m}^{-3}$ as the critical density for DSW. Figure 12 shows a dependence of the estimated DSW outflow transport on the selected cutoff potential density. Since the dependence on density at $27.88 \mathrm{~kg} \mathrm{~m}^{-3}$ is not small, our estimate is sensitive to the prescribed cutoff density and will be addressed further in the discussion section.

To examine the potential temperature-salinity characteristics of water masses exchanged across the northern boundary, the net transport is calculated in the potential temperature-salinity space with bin intervals of $0.1{ }^{\circ} \mathrm{C}$ and $0.02 \mathrm{psu}$ (Fig. 13). The outflow of DSW denser than $\sigma_{\theta}=27.88 \mathrm{~kg} \mathrm{~m}^{-3}$ becomes notable from July to November. From December to March, the main component of the outflow is in the areas corresponding to modified Shelf Water (mSW), indicating that remnant DSW in the Adélie Depression mixes with the mCDW penetrating from the shelf break and the resulting 
water mass flows out through the Adélie Sill. From April to June, there is no notable outflow of DSW, only $\mathrm{mCDW} / \mathrm{mSW}$.

Figure 14 shows the seasonal variation of ratio of waters classified by potential density bins of $0.02 \mathrm{~kg} \mathrm{~m}^{-3}$ width in the control volume. The ratio of DSW reaches the maximum of about $55 \%$ in September and a minimum of about $5 \%$ in June. The amount of remnant DSW in the Adélie Depression in June is smaller by one order of magnitude than outflow volume of DSW from the Adélie Depression in the year. This fact indicates that the newlyformed DSW in the Adélie Depression is depleted by outflow and mixing with $\mathrm{mCDW}$ within the year, i.e. there is little storage or accumulation of DSW from year to year.

\subsection{Mertz Depression}

As in the case of the Adélie Depression, there are two distinct seasonal flow patterns in the Mertz Depression: a vertical circulation formed in the depression during winter and a surface-intensified clockwise horizontal circulation trapped over the depression during summer (Figs. 8 and 9). Coastal polynyas form in lee side of a near-meridional line of grounded icebergs, including iceberg B9-b, along $148-149^{\circ} \mathrm{E}$ and show high sea ice production (Fig. 2b). Sea ice productions over the Adélie and Mertz Depressions (sums over areas enclosed by solid lines and coastline/grounded icebergs in Fig. 2b) are $219 \mathrm{~km}^{3}$ and $120 \mathrm{~km}^{3}$, respectively. The sea ice production in the Mertz Depression accounts for about 35\% of total sea ice production in the AGVL region, consistent with observational analysis (Williams et al., 2010). There are intrusions of AASW and mCDW from shelf break into the Mertz Depression along the western flank of the Ninnis Bank (Fig. 8). Along these 
intrusions, potential temperature is maximum at intermediate depths. The slope of the density front formed over the western flank of the Ninnis Bank is weaker than that formed over the southwestern flank of the Mertz Bank in the Adélie Depression. The densest waters $\left(\sigma_{\theta}>27.90 \mathrm{~kg} \mathrm{~m}^{-3}\right)$ are found along the southern and western flanks of the Mertz Depression. Along the weak density front, bottom dense water flows toward the Mertz Sill against the western side of the Mertz Depression.

There is a distinct outflow of DSW from the Mertz Depression. The density of outflowing DSW from the Mertz Depression is lighter than that from the Adélie depression (Fig. 12). Outflowing waters denser than $27.88 \mathrm{~kg} \mathrm{~m}^{-3}$ in the Mertz Depression are found from August to December, and the period of outflowing DSW is shorter than in the Adélie Depression (Fig. 15). Annual mean export of waters denser than $\sigma_{\theta}=27.88(27.80) \mathrm{kg} \mathrm{m}^{-3}$ from the Mertz Sill is $0.12(0.32) \mathrm{Sv}$. The model demonstrates the dual-system for DSW formation and export from the Adélie and Mertz depressions described by observations (Williams et al., 2010) and confirms that the Mertz Depression produces less DSW, over a shorter period of time. 


\section{Mechanism of the ocean circulations}

\subsection{Idealized experiments}

In the initial simulation (hereafter referred to as CTRL), the ocean circulations in the Adélie and Mertz Depressions are characterized by two distinct patterns for winter and summer. In the Adélie Depression in winter, a vertical circulation developed over the southwestern flank of the Mertz Bank and consists of a southeastward flow in the upper layer toward the Mertz Glacier Tongue and a northwestward flow in the lower layer toward the Adélie Sill. In summer there is a surface-intensified clockwise horizontal circulation which is trapped over the Adélie Depression. In this section, we focus on the Adélie Depression and perform a series of idealized numerical experiments to investigate the mechanisms driving the two distinct seasonal circulations.

The setup of the idealized experiments is summarized in Table 1. The coastline and topography is the same as in CTRL. For simplicity, a standalone ocean model is used for these experiments, and idealized surface freshwater flux and wind stress are imposed. EXP1 is driven only by surface freshwater flux which corresponds to sea ice production of $10 \mathrm{~cm} \mathrm{~s}^{-1}$. The forcing area is between $140^{\circ} \mathrm{E}$ and $146.2^{\circ} \mathrm{E}$ and within $30 \mathrm{~km}$ distance from the coast. After a 1-year integration a quasi-steady state in the Adélie Depression is achieved. EXP2 and EXP3 are driven only by the surface wind stress of winter and summer, respectively, calculated from the climatology of Röske (2006). In these cases a quasi-steady state is obtained after a 90-day integration. The initial condition for the three experiments has a uniform tracer distribution (potential temperature at $-1.0^{\circ} \mathrm{C}$ and salinity at $34.0 \mathrm{psu}$ ) and zero velocity over the entire model domain. The initial condition for 
EXP4 and EXP5 is the final state of EXP1. No surface forcing is imposed in EXP4, and only the summertime wind stress is imposed in EXP5.

\subsection{Results of idealized experiments}

Figure 16 shows the results (potential density anomaly referenced to the initial condition and velocity) of EXP1 and EXP4, which are averaged over the last 60 days. In EXP1 (Fig 16a-d), there is a density front between a dense water mass formed in the coastal area and the lighter water mass over the southwestern flank of the Mertz Bank that comes from the shelf break. In the subsurface layer, there is flow toward the Mertz Glacier Tongue. There is a flow of dense water from the Mertz Glacier Tongue to the Adélie Sill along the density front in the middle and lower layers, and a dense water mass flows out from the Adélie Sill. These features are similar to wintertime in the CTRL.

There are two qualitative differences between EXP1 and CTRL. Firstly, Antarctic Slope Front (ASF) and Current (ASC) does not exist over the continental slope, and thus the strong westward flow along the ASC is lacking in EXP1. Secondly, the light water in the surface layer in EXP1 flows eastward with the dense water formed in the coastal area on the right. These differences are caused by the difference in stratification between the initial conditions. In EXP4 (Fig 16e-h), there is a surface-intensified clockwise circulation in the Adélie Depression, i.e., there is a dome of positive density anomaly at the center of circulation. These features are similar to the summertime situation of CTRL. Velocities in the Adélie Depression for EXP2 and EXP3 are smaller by one order of magnitude than those in EXP1, and there is no pronounced circulation (not shown). The flow pattern in EXP5 
is similar to that in EXP4. This implies that wind stress is not the main driving force for the circulation in the Adélie Depression.

${ }_{528}$ These results indicate that the vertical circulation in winter is driven by 529 the brine rejection in the coastal polynyas and that the surface-intensified 530 clockwise circulation in summer results from the cessation of sea-ice produc531 tion. The seasonal variation in the circulation in the Adélie Depression can 532 be understood as spinning-up and down of the haline circulation driven by ${ }_{533}$ brine rejection, a phenomenon that has been documented for the large-scale 534 global thermohaline circulation (e.g., Kawase, 1987; Suginohara and Fuka535 sawa, 1988). While the haline circulation presented here is more localized, ${ }_{536}$ the basic physics are the same. The same mechanism is also valid for the 537 seasonal variation of circulation in the Mertz Depression. 


\section{Summary and Discussion}

In this study we used a global ice-ocean model to investigate the formation and export of DSW from Adélie and George V Land. The model reproduces the observed features of winter hydrography in the Adélie Depression such as a warm mCDW intrusion at intermediate depths and a low salinity AASW in the surface layer (Figs. 3 and 5). The model also reproduces the amplitude and phase of the seasonal variation of potential density observed at mooring sites near the Mertz Glacier Tongue and just south of the Adélie Sill (Fig. $6 a)$.

The modeled circulations in the Adélie and Mertz Depressions are characterized by two distinct flow patterns during winter and summer (Figs. 8 and 9). In the two depressions, a vertical circulation develops in winter and a surface-intensified clockwise circulation is formed in summer. From a series of idealized experiments (Table 1 and Fig. 16), these circulations in the depressions are shown to be the result of a spinning-up and down of haline circulation driven by brine rejection at coastal polynyas, unrelated to the surface wind stress.

In the Adélie Depression, the vertical circulation consists of a southeastward flow in the upper layer towards the Mertz Glacier Tongue and a northwestward flow in the lower layer toward the Adélie Sill (Figs. 3, 5, and 8). These flows are associated with a density front along the southwestern flank of the Mertz Bank. The density front is formed between dense waters formed in the coastal area and lighter waters that originated from the shelf break. The wintertime northwestward bottom flow is connected to the outflow of dense waters from the Adélie Depression. 
The outflow of DSW from the Adélie Depression is predominantly through the Adélie Sill. The outflow of the densest classes of shelf water (DSW) has a bottom intensified structure under the density front at the Adélie Sill. The wintertime outflow of dense water from the Adélie Sill is compensated by the inflow of AASW and mCDW across the shelf break (Fig. 11). AASW flows into the Adélie Depression across the shelf break over a wide zonal extent and with a thickness of 100-200 m (Fig. 10a). The inflow of mCDW is confined in the strong density front formed over the southwestern flank of the Mertz Bank and bottom topography (Figs. 3 and 10a).

The model clearly shows a dual-system for the formation and export of DSW from the Adélie and Mertz Depressions (Fig. 12), consistent with recent observational analysis over the upper continental slope and lower continental rise (Williams et al., 2010). Assuming a critical (cutoff) potential density for DSW of $27.88(27.80) \mathrm{kg} \mathrm{m}^{-3}$, the annual mean transport to the open ocean across the Adélie and Mertz Sills are estimated to be 0.21 (0.37) Sv and $0.12(0.32)$ Sv, respectively. This modeled DSW export from Adélie Sill is consistent with previous observational and model studies (Table 2).

However, the DSW export in this study is likely to be overestimated because the modeled potential density of outflow is biased to the higher density. Assuming the bias of potential density is $0.04 \mathrm{~kg} \mathrm{~m}^{-3}$ (Figs. 4 and 6), the above DSW exports from Adélie and Mertz Sills are re-estimated to be $0.12(0.30) \mathrm{Sv}$ and $0.05(0.22) \mathrm{Sv}$, respectively (Table 2).

The property of outflowing dense water through the Adélie Depression corresponds to DSW from July to November, and mSW from December to March, indicating that DSW in the Adélie Depression is mixed with the pen- 
etrating $\mathrm{mCDW}$ from the shelf break and the mixed water outflows through the Adélie Sill (Figs. 13 and 14). The density of the DSW outflow from the Mertz Depression is lighter than that from the Adélie Depression and has a shorter export season (Figs. 13 and 15).

Marsland et al. (2004) showed the wintertime overturning circulation in the Adélie Depression linked with coastal polynya processes using an iceocean model. Their medium horizontal resolution over the Adélie Depression was not enough to resolve key features of bottom topography for reproducing the ocean circulation there, where a horizontal resolution as high as a few kilometers is needed to realistically reproduce the observed features in the AGVL region. In this study, we demonstrate for the first time that a high resolution model can realistically reproduce the observed features across the entire AGVL region and can be a powerful tool for studying Antarctic coastal polynya systems.

In this study, the grid points for ice shelves are treated as land. However, in reality there is an interaction between the ocean and the ice shelves. This interaction is considered to lead to melting ice shelves and adding freshwater into the ocean, which could modify sea ice distributions and water mass formations (Hellmer, 2004). Losch (2008) proposed a new ice shelf cavity model for z coordinate ocean models. Such an ice shelf cavity model is currently under development for use in COCO.

In the present model, the downslope mixing of dense shelf water over the slope is not well reproduced (Wang et al., 2008), due mainly to the coarse vertical resolution (grid thickness is 50 - $100 \mathrm{~m}$ over the continental slope). To effectively reproduce downslope flows over the continental slope 
613 and the reciprocal ascending plumes of ice shelf water beneath ice shelves, 614 much higher vertical resolution (about $20 \mathrm{~m}$ ) is required to explicitly resolve 615 the boundary layers between the ocean and solid boundaries. 
Adcroft, A., Hill, C., Marshall, J., 1997. Representation of topography by shaved cells in a height coordinate ocean model. Monthly Weather Review 125 (9), 2293-2315.

Bindoff, N. L., Rosenberg, M. A., Warner., M. J., 2000. On the circulation and water masses over the Antarctic continental slope and rise between 80 and $150^{\circ}$ E. Deep-Sea Research Part II 47 (12-13), 2299-2326.

Bindoff, N. L., Williams, G. D., Allison, I., 2001. Sea-ice growth and watermass modification in the Mertz Glacier polynya, East Antarctica, during winter. Annals of Glaciology 33, 399-406.

Bitz, C. M., Lipscomb, W. H., 7 1999. An energy-conserving thermodynamics model of sea ice. J. Geophys. Res. 104 (C7), 15669-15677.

Foldvik, A., Gammelsrød, T., Østerhus, S., Fahrbach, E., Rohardt, R., Schröder, M., Nicholls, K. W., Padman, L., Woodgate, R. A., 2004. Ice shelf water overflow and bottom water formation in the southern Weddell Sea. JGR 109 (C02015).

Gent, P. R., Willbrand, J., McDougall, T. J., McWilliams, J. C., 1995. Parameterizing eddy-induced tracer transports in ocean circulation models. J. Phys. Oceanogr. 25, 463-474.

Gordon, A. L., Tchernia, P., 1972. Water of the continental margin off Adélie coast, Antarctica. Vol. 19 of Antarctic Research Series, Antarctic Oceanology II. American Geophysical Union, Washington.

Haran, T., Bohlander, J., Scambos, T., Painter, T., Fahnestock, M., 2005. 
MODIS mosaic of Antarctica (MOA) image map. National Snow and Ice Data Center, Boulder, Colorado USA, digital media, updated 2006.

Hasumi, H., 2006. Ocean Component Model (COCO) version 4.0. CCSR Report 25, Center for Climate System Research, University of Tokyo.

Hellmer, H. H., 2004. Impact of Antarctic ice shelf basal melting on sea ice and deep ocean properties. Geophys. Res. Lett. 31 (L10307), doi:10.1029/2004GL019506.

Hibler, W. D., 1979. A dynamic thermodynamic sea ice model. J. Phys. Oceanogr. 9, 815-846.

Hunke, E. C., Dukowicz, J. K., 9 1997. An Elastic-Viscous-Plastic model for sea ice dynamics. J. Phys. Oceanogr. 27, 1849-1867.

IOC, IHO, BODC, 1994. Supporting volume to the GEBCO digital atlas, published on behalf of the Intergovermental Oceanographic Commision (of UNESCO) and the International Organisation as part of the General Bathymetric Chart of the Ocean (GEBCO), British Oceanographic Data Centre, Birkenhead.

Jackett, D. R., McDougall, T. J., 2 1997. A neutral density variable for the world's oceans. J. Phys. Oceanogr. 27, 237-263.

Kalnay, E., 1996. The NCEP/NCAR 40 year-reanalysis project. Bull. Am. Meteorol. Soc. 77, 437-470.

Kara, A. B., 10 2000. Efficient and accurate bulk parameterizations of air-sea 
fluxes for use in General Circulation Models. J. Atmos. Ocean. Technol. $17,1421-1438$.

Kawase, M., 12 1987. Establishment of deep ocean circulation driven by deep-water production. J. Phys. Oceanogr. 17 (12), 2294-2317.

Kusahara, K., Hasumi, H., Tamura, T., 2010. Modeling sea ice production and dense shelf water formation in coastal polynyas around East Antarctica. J. Geophys. Res. 115, C10006.

Leonard, B. P., MacVean, M. K., Lock, A. P., 1993. Positivity-preserving numerical schemes for multidimensional advection. Tech. Memo 106005, NASA, 62pp.

Losch, M., 2008. Modeling ice shelf cavities in a $\mathrm{z}$ coordinate ocean general circulation model. J. Geophys. Res. 113 (C08043), doi:10.1029/2007JC004368.

Marsland, S. J., Bindoff, N. L., Williams, G. D., Budd, W. F., 2004. Modeling water mass formation in the Mertz Glacier Polynya and Adélie Depression, East Antarctica. J. Geophys. Res 109 (C11), C11003.

Marsland, S. J., Church, J. A., Bindoff, N. L., Williams, G. D., 2007. Antarctic coastal polynya response to climate change. J. Geophys. Res. 112, C07009.

Massom, R. A., Harris, P. T., Michael, K. J., Potter, M. J., 1998. The distribution and formative processes of latent-heat polynyas in East Antarctica. Annals of Glaciology 27, 420-426. 
Mellor, G. L., Kantha, L., 8 1989. An ice-ocean coupled model. J. Geophys. Res. 94 (C8), 10937-10954.

Noh, Y., Kim, H. J., 1999. Simulations of temperature and turbulence structure of the oceanic boundary layer with the improved near-surface process. J. Geophys. Res. 104 (C7), 15621-15634.

Orsi, A. H., Johnson, G. C., Bullister, J. L., 1999. Circulation, mixing, and production of Antarctic Bottom Water. Progress in Oceanography 43 (1), $55-109$.

Orsi, A. H., Wiederwohl, C. L., 2009. A recount of Ross Sea waters. Deep-Sea Research Part II 56, 778-795.

Porter-Smith, R., 2003. Bathymetry of the George Vth Land shelf and slope. Deep-Sea Res. 50, 1337-1347.

Rintoul, S. R., 1998. On the origin and influence of Adelie Land Bottom Water. Vol. 75 of Interactions at the Antarctic Continental Margin, Antarct. Res. Ser. American Geophysical Union, Washington, D.C.

Röske, F., 2006. A global heat and freshwater forcing dataset for ocean models. Ocean Modelling 11, 235-297.

Schlosser, P., Bayer, R., Foldvik, A., Gammerlsrød, T., Rohardt, G., Münnich, K. O., 3 1990. Oxygen 18 and Helium as tracers of Ice Shelf Water and water/ice interaction in the Weddell Sea. J. Geophys. Res. 95 (C3), 3253-3263. 
Smethie Jr., W. M., Jacobs, S. S., 2005. Circulation and melting under the Ross Ice Shelf: estimates from evolving CFC, salinity and temperature fields in the Ross Sea. Deep-Sea Res. 52, 959-978.

Steele, M., Morley, R., Ermold, W., 2001. PHC: A global ocean hydrography with a high-quality Arctic Ocean. J. Climate 14, 2079-2087.

Suginohara, N., Fukasawa, M., 1988. Set-up of deep circulation in multi-level numerical models. J. Oceanogr. 44 (6), 315-336.

Tamura, T., Ohshima, K. I., Nihashi, S., 2008. Mapping of sea ice production for Antarctic coastal polynyas. Geophys. Res. Lett. 35, L07606.

Tsujino, H., Hasumi, H., Suginohara, N., 2000. Deep Pacific circulation controlled by vertical diffusivity at the lower thermocline depths. Journal of Physical Oceanography 30 (11), 2853-2865.

Wang, Q., Danilov, S., Schröter, J., 2008. Comparison of overflow simulations on different vertical grids using the finite element ocean circulation model. Ocean Modelling 20, 313-335.

Williams, G. D., Aoki, S., Jacobs, S. S., Rintoul, S. R., Tamura, T., Bindoff, N. L., 2010. Antarctic Bottom Water from the Adelie and George V land coast, East Antarctica (140 - 149E). J. Geophys. Res. 115 (C04027).

Williams, G. D., Bindoff, N. L., 2003. Wintertime oceanography of the Adélie Depression. Deep-Sea Res. 50, 1373-1392. 
${ }_{722}$ Williams, G. D., Bindoff, N. L., Marsland, S. J., Rintoul, S. R., 2008. For${ }_{723}$ mation and export of dense shelf water from the Adélie Depression, East $724 \quad$ Antarctica. J. Geophys. Res. 113, C04039. 
Table 1: Summary of idealized experiments.

\begin{tabular}{ccccc}
\hline \hline & Initial Condition & Freshwater Flux & Wind Stress & Period \\
\hline \hline EXP1 & $\mathrm{T}=-1.0^{\circ} \mathrm{C}, \mathrm{S}=34.0 \mathrm{psu}$ & $\sqrt{ }^{*}$ & - & 360 \\
EXP2 & $\mathrm{T}=-1.0^{\circ} \mathrm{C}, \mathrm{S}=34.0 \mathrm{psu}$ & - & JJA & 90 \\
EXP3 & $\mathrm{T}=-1.0^{\circ} \mathrm{C}, \mathrm{S}=34.0 \mathrm{psu}$ & - & DJF & 90 \\
EXP4 & Final state of EXP1 & - & - & 180 \\
EXP5 & Final state of EXP1 & - & DJF & 180 \\
\hline \hline
\end{tabular}

*: Freshwater flux corresponding to a sea ice production of $10 \mathrm{~cm} /$ day. 
Table 2: Comparison with previous studies

\begin{tabular}{lll}
\hline \hline Source & Water mass & DSW export (Sv) \\
\hline Adélie Sill & & \\
Williams et al. (2008) & $\sigma_{\theta}>27.88$ & $0.1-0.5$ \\
Marsland et al. (2004) & $\sigma_{\theta}>27.88$ & 0.15 \\
This study & $\sigma_{\theta}>27.88$ & $0.21 \pm 0.05$ \\
& $\sigma_{\theta}>27.88+0.04$ & $0.12 \pm 0.05$ \\
& $\sigma_{\theta}>27.80$ & $0.37 \pm 0.04$ \\
& $\sigma_{\theta}>27.80+0.04$ & $0.30 \pm 0.05$ \\
Mertz Sill & & \\
This study & $\sigma_{\theta}>27.88$ & $0.12 \pm 0.07$ \\
& $\sigma_{\theta}>27.88+0.04$ & $0.05 \pm 0.05$ \\
& $\sigma_{\theta}>27.80$ & $0.32 \pm 0.07$ \\
\hline \hline
\end{tabular}


Figure 1 Bathymetry of the model (a: Southern Ocean, b: around the AGVL region). In b), horizontal grid spacing is shown by red dashed lines and grounded icebergs are shown by the crosses. See the caption of Fig. 2 for the abbreviations of place names.

Figure 2 Topography around the AGVL region. a) The blue dashed and solid lines indicate the Shelf-Break and Loop sections, respectively. The green boxes labeled by A (depression region) and B (sill region) indicate areas used for averaging model results. The red dashed line is the boundary of the control volume. Crosses show the locations of grounded icebergs. Abbreviations of the place names are as follows: Adélie Bank (AB), Adélie Depression (AD), Adélie Sill (AS), Mertz Bank (MB), Commonwealth Bay (CB), Watt Bay (WB), Buchanan Bay (BB), Mertz Glacier Tongue (MGT), Mertz Depression (MD), Mertz Sill (MS), Ninnis Bank (NB), and B9b iceberg (B9b). b) Net sea ice production (m/year). The area of net sea ice production smaller than $2 \mathrm{~m}$ is masked out. The orange lines define areas for calculating sea ice production.

Figure 3 Vertical sections of (a) potential temperature $\left({ }^{\circ} \mathrm{C}\right)$, (b) salinity (psu), and (c) potential density $\left(\mathrm{kg} \mathrm{m}^{-3}\right)$ in August along the Shelf-Break section (see blue dashed line with circles in Fig. 2a). Colored circles indicate observed values of potential temperature and salinity (Williams and Bindoff, 2003). Black contours in panel c) show the velocity normal to the section $(\mathrm{cm} / \mathrm{s})$. Positive (negative) velocity indicates offshore (onshore) direction and the negative values are hatched. Distance in the horizontal axis is mea- 
sured from station 58. Dashed blue and red lines indicate the neutral density surfaces of 28.00 and $28.27 \mathrm{~kg} \mathrm{~m}^{-3}$, respectively. The solid blue line indicates the potential density surface of $27.88 \mathrm{~kg} \mathrm{~m}^{-3}$.

Figure 4 Vertical profiles of potential temperature, salinity and potential density at stations 57, 59, L4 and L9 (see the locations in Fig. 2a) in August. The solid line and gray shading shows the modeled mean and standard deviation, respectively, and the dashed line shows the modeled value in 1998 . Circles indicate the observed value of Williams and Bindoff (2003).

Figure 5 As in Figure 3, but along the Loop section. Positive (negative) velocity indicates outward (inward) direction. Averaged values over three Loop transects are used for the observed potential temperature and salinity (Williams and Bindoff, 2003).

Figure 6 Seasonal variation of potential density near the Mertz Glacier Tongue (area A, depression region) and just south of the Adélie Sill (area B, sill region). The contour interval in a) and b) is $0.02 \mathrm{~kg} / \mathrm{m}^{3}$ and the values larger than $27.88 \mathrm{~kg} / \mathrm{m}^{3}$ are shaded. The horizontal dashed lines indicate depths of $425 \mathrm{~m}$ and $575 \mathrm{~m}$. c) Timeseries of the potential density at $425 \mathrm{~m}$ and $575 \mathrm{~m}$, averaged over areas A and B in the model (thick lines), and from the observations (thin lines with dots). 
Figure 7 Seasonal variation of sea ice production in the Adélie Depression. Gray colors indicate distance from the coast $(\mathrm{km})$.

Figure 8 Potential density, temperature, and velocity fields at surface (0 $50 \mathrm{~m})$, subsurface $(125 \mathrm{~m})$, intermediate $(275 \mathrm{~m})$, and lower $(425 \mathrm{~m})$ layers in September. Dashed blue and red lines indicate the neutral density surfaces of 28.00 and $28.27 \mathrm{~kg} \mathrm{~m}^{-3}$, respectively. Solid blue lines indicate the potential density surface of $27.88 \mathrm{~kg} \mathrm{~m}^{-3}$. Gray lines show the depth contours, with $100 \mathrm{~m}(500 \mathrm{~m})$ intervals in the regions shallower (deeper) than $500 \mathrm{~m}$. Some vectors are thinned out for clarity. Numbers with red circles indicate mb1, $\mathrm{mb} 2, \mathrm{mb} 3$, and mb4.

Figure 9 As in Figure 8, but in February.

Figure 10 Vertical sections of potential density $\left(\mathrm{kg} \mathrm{m}^{-3}\right)$ along the boundaries of the control volume in (a) September and (b) February. Black contours show the velocity normal to the section $(\mathrm{cm} / \mathrm{s})$. Positive (negative) velocity indicates outward (inward) flow. Negative values are hatched. Dashed blue and red lines indicate the neutral density surfaces of 28.00 and $28.27 \mathrm{~kg} \mathrm{~m}^{-3}$, respectively. Solid blue line indicates the potential density surface of $27.88 \mathrm{~kg} \mathrm{~m}^{-3}$.

Figure 11 Seasonal variation of net transport across control volume boundary in $0.02 \mathrm{~kg} \mathrm{~m}^{-3}$ potential density bins. Positive values indicate out- 
flow from the control volume. Blue lines indicate the potential density of $27.88 \mathrm{~kg} \mathrm{~m}^{-3}$. In b), the vertical blue bars show the standard deviation of interannual variability for $\sigma_{\theta}=27.88 \mathrm{~kg} \mathrm{~m}^{-3}$.

Figure 12 Dependence of annual mean DSW transport from the Adélie (circles) and Mertz (squares) Sills on the cutoff density. Error bars indicate the standard deviation of interannual variability and are only shown for the DSW transport from the Adélie Depression for clarity.

Figure 13 Seasonal variation of water exchange across the northern boundary of the Adélie Depression in potential temperature-salinity space. Dashed blue and red lines show the neutral density of 28.00 and $28.27 \mathrm{~kg} \mathrm{~m}^{-3}$, respectively. Blue thick and thin lines show the potential density of 27.88 and $27.80 \mathrm{~kg} \mathrm{~m}^{-3}$, respectively.

Figure 14 Ratio of water masses in the control volume. The total volume of the control volume is $8.82 \times 10^{6} \mathrm{~km}^{3}$. Dashed blue and red lines indicate the neutral density surfaces of 28.00 and $28.27 \mathrm{~kg} \mathrm{~m}^{-3}$, respectively. The solid blue line indicates the potential density surface of $27.88 \mathrm{~kg} \mathrm{~m}^{-3}$. Vertical blue bars show the standard deviation of interannual variability for $\sigma_{\theta}=27.88 \mathrm{~kg} \mathrm{~m}^{-3}$

Figure 15 As in Figure 13, but across the Mertz Sill. 
807 808

810

811

812

(10)

Figure 16 Potential density anomaly (relative to the initial density) and velocity fields at surface $(0-50 \mathrm{~m})$, subsurface $(125 \mathrm{~m})$, intermediate $(275$ $\mathrm{m})$, and lower (425 m) layers for (a-d) EXP1 and (e-h) EXP4. 


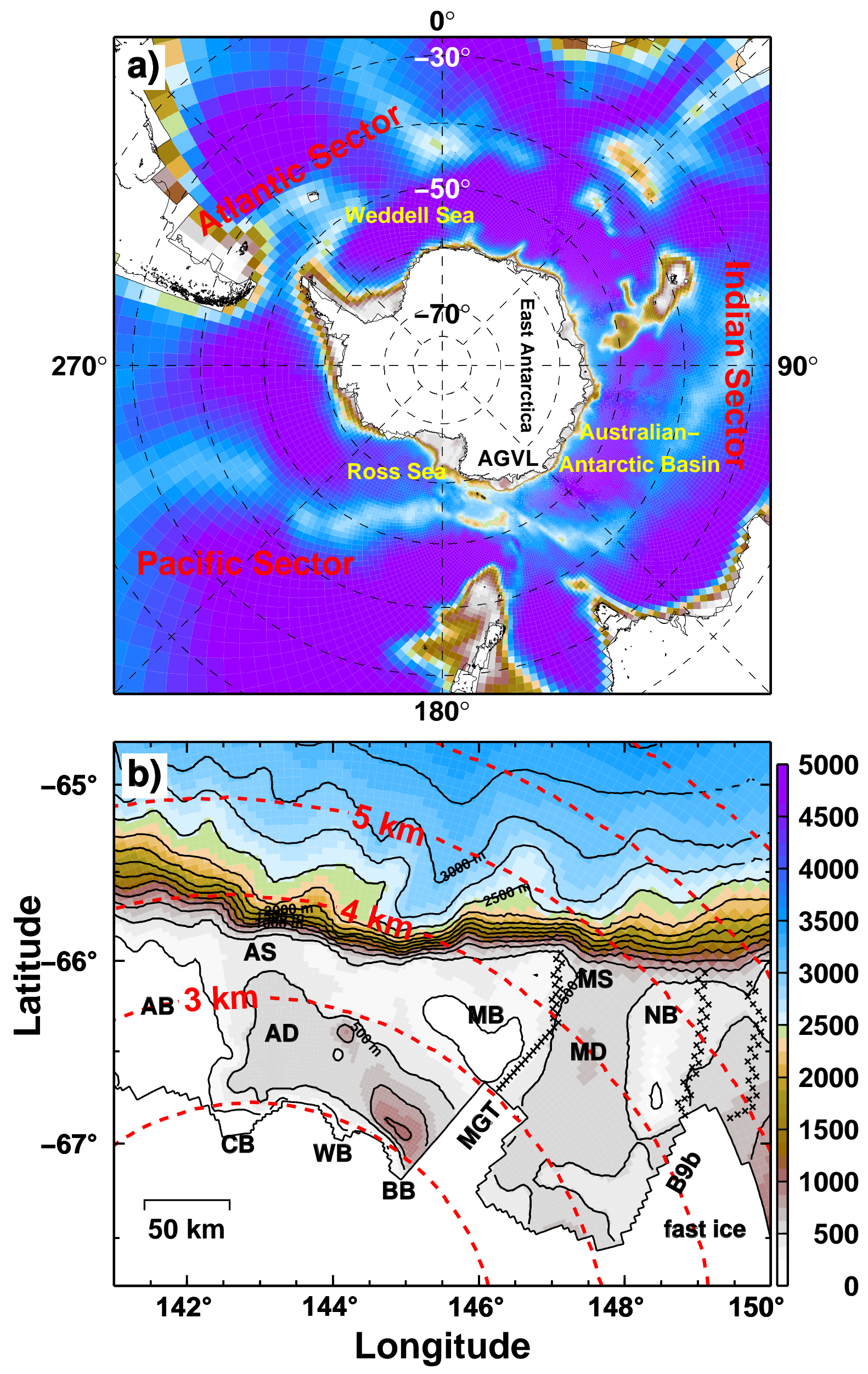

Figure 1: 
a) Topography, Sections, and Stations

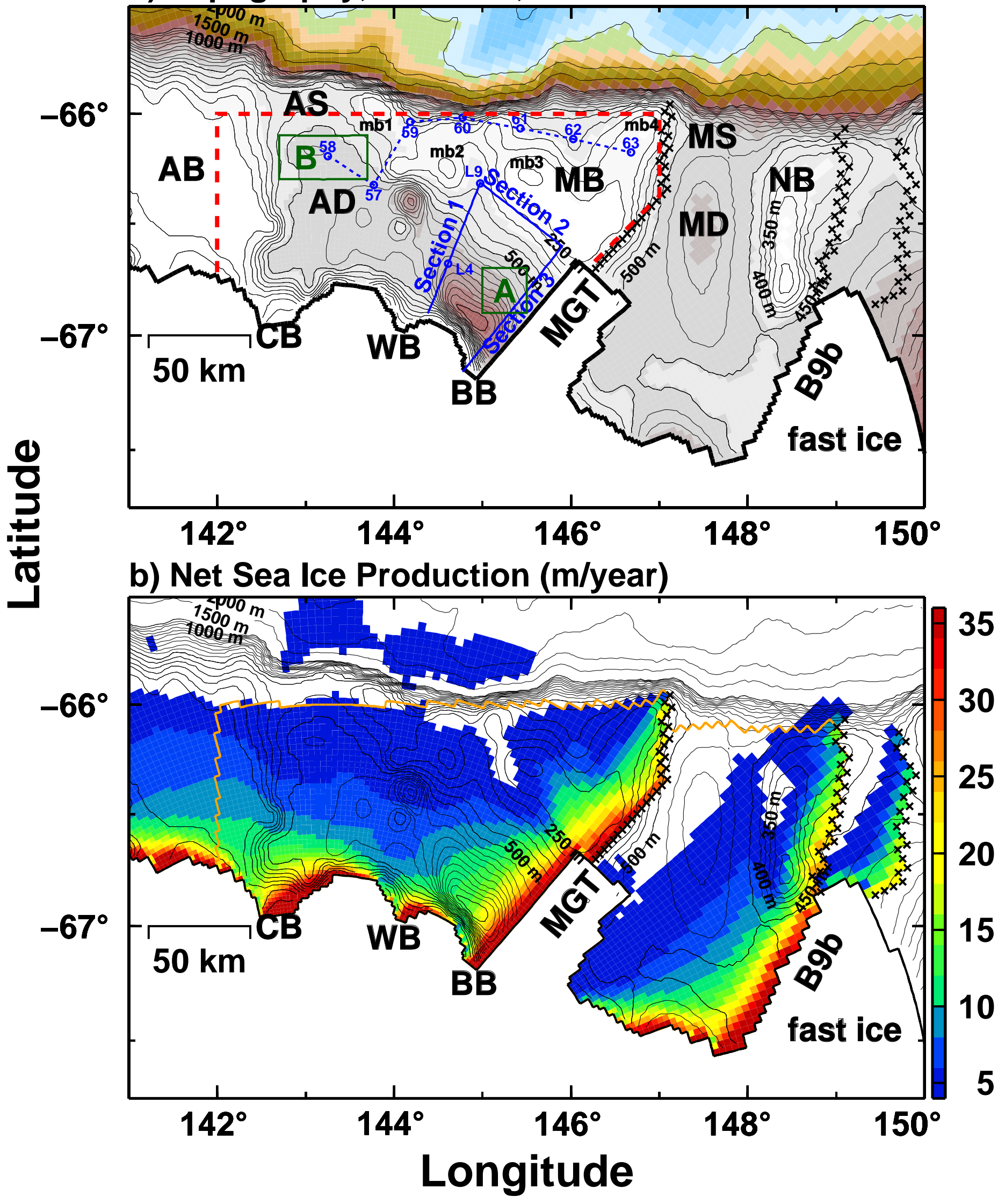




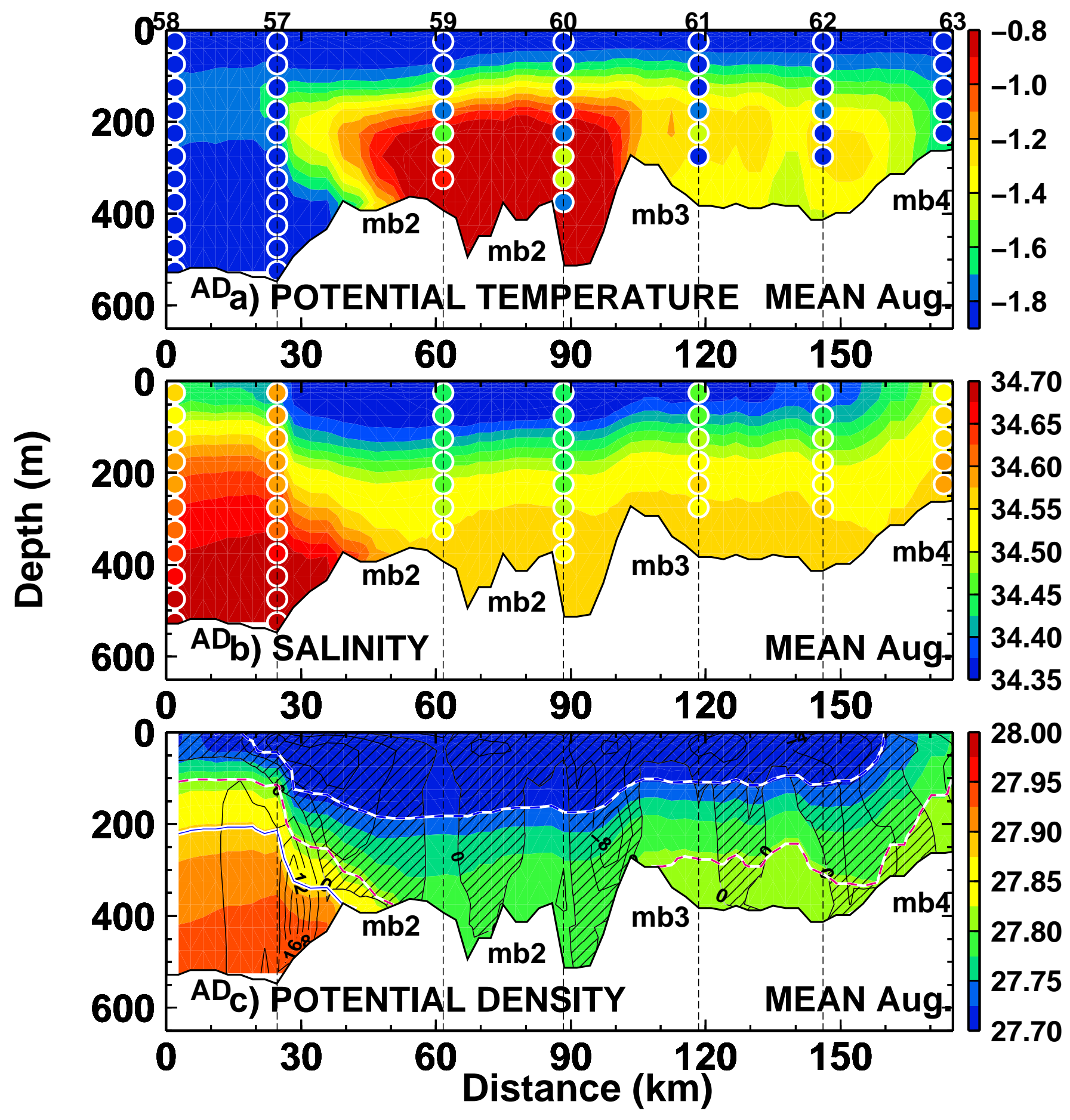

Figure 3: 

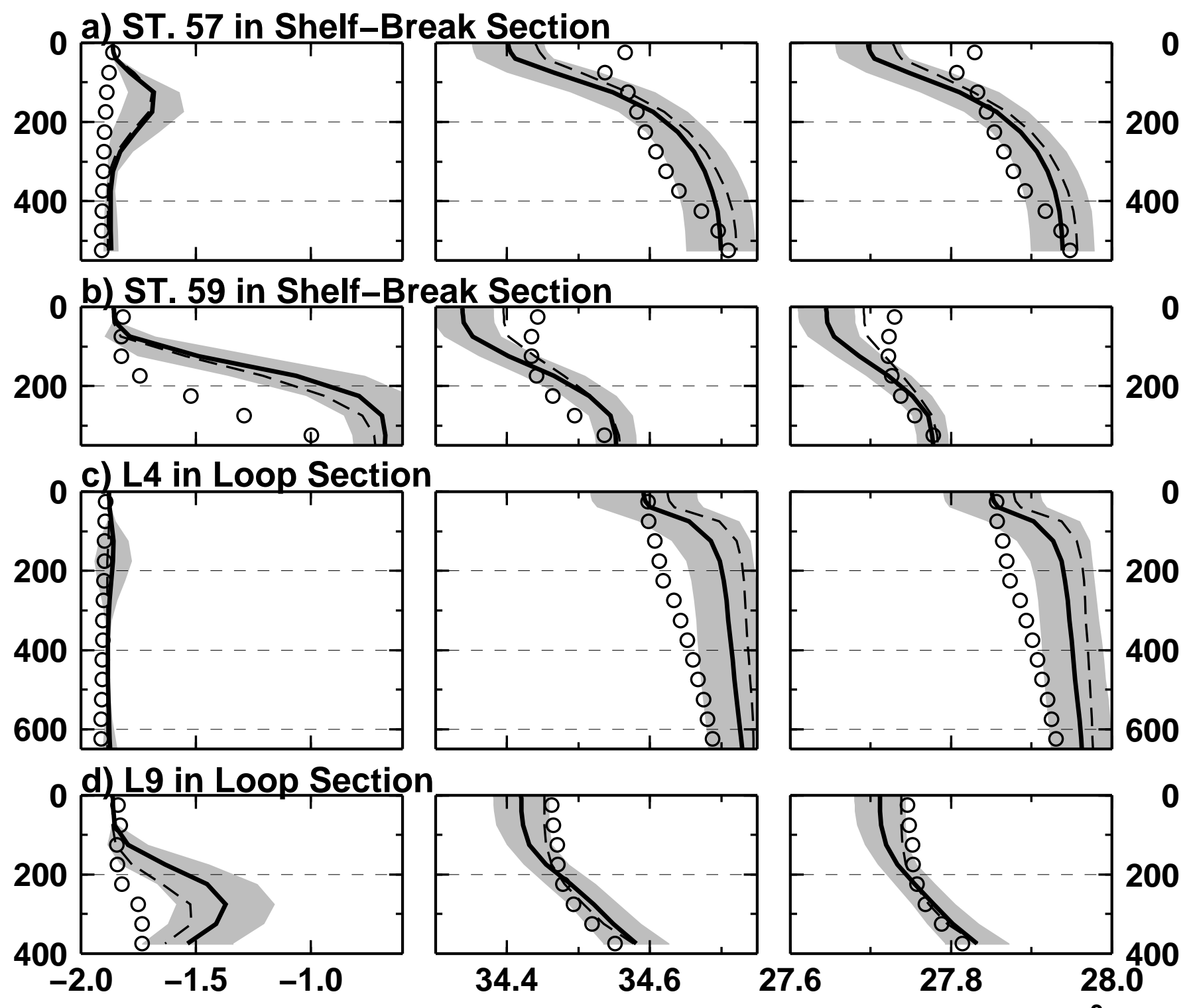

TEMPERATURE $\left({ }^{\circ} \mathrm{C}\right)$

SALINITY (psu)

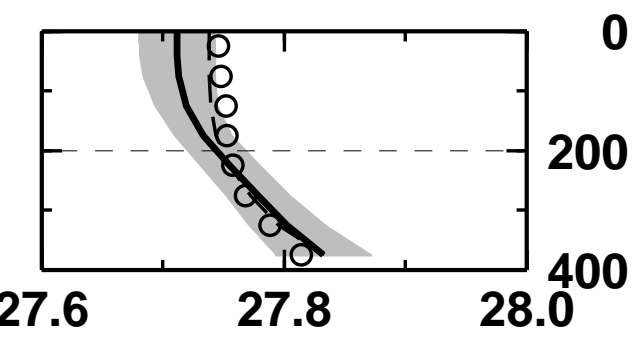

DENSITY ( $\left.\mathrm{kg} \mathrm{m}^{-3}\right)$

Figure 4: 


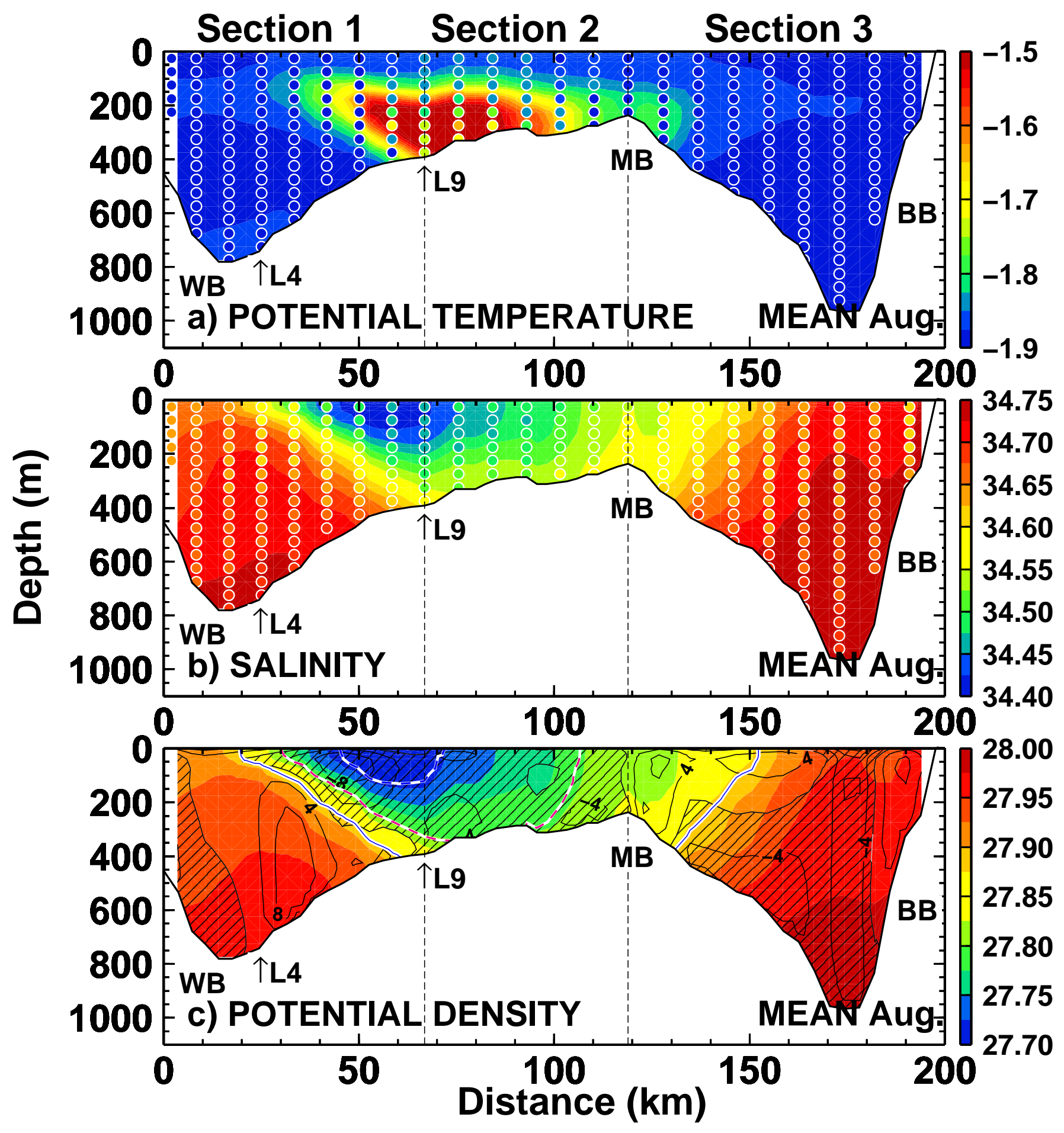

Figure 5: 

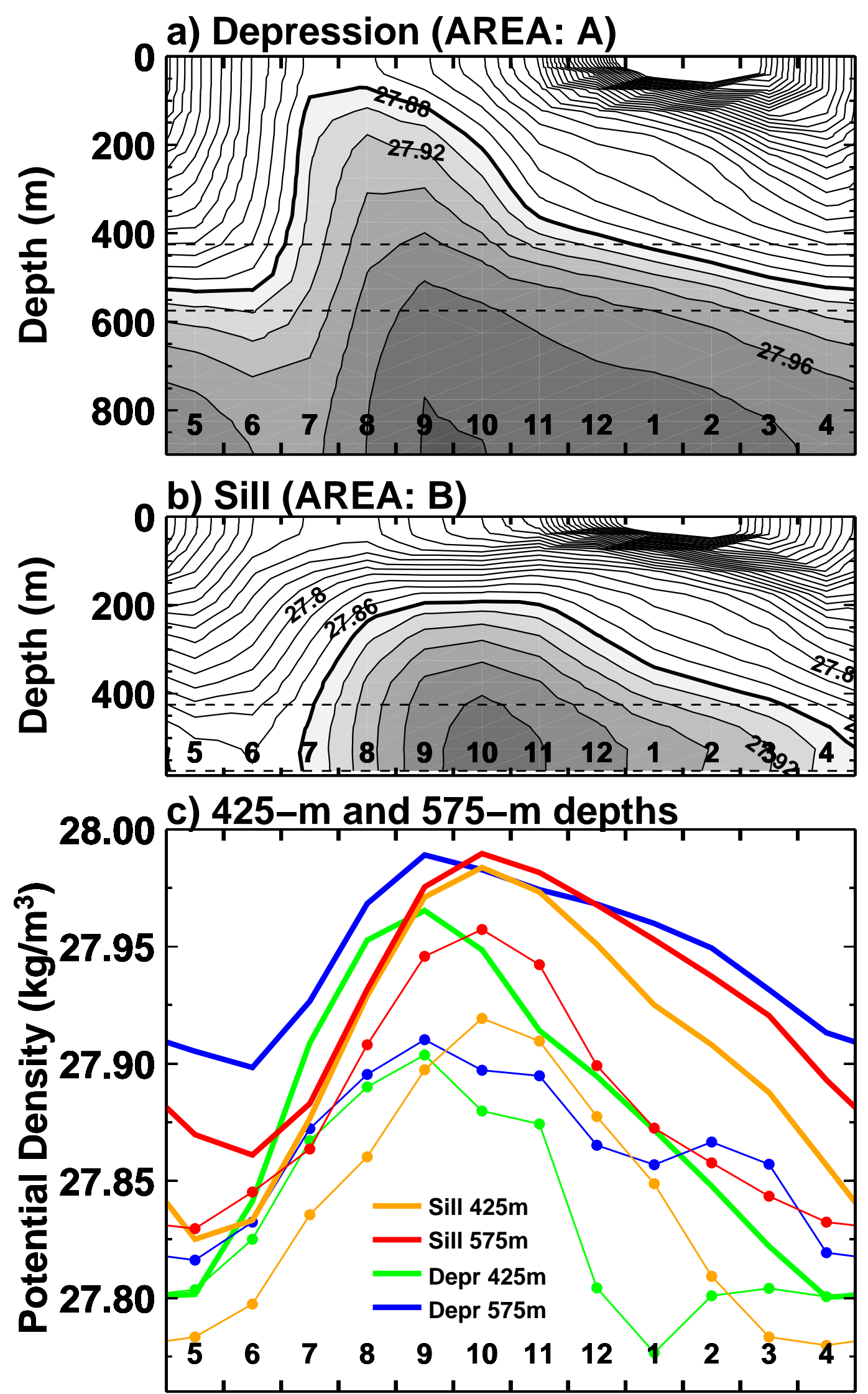

May Jun. Jul. Aug. Sep. Oct. Nov. Dec. Jan. Feb. Mar. Apr. 


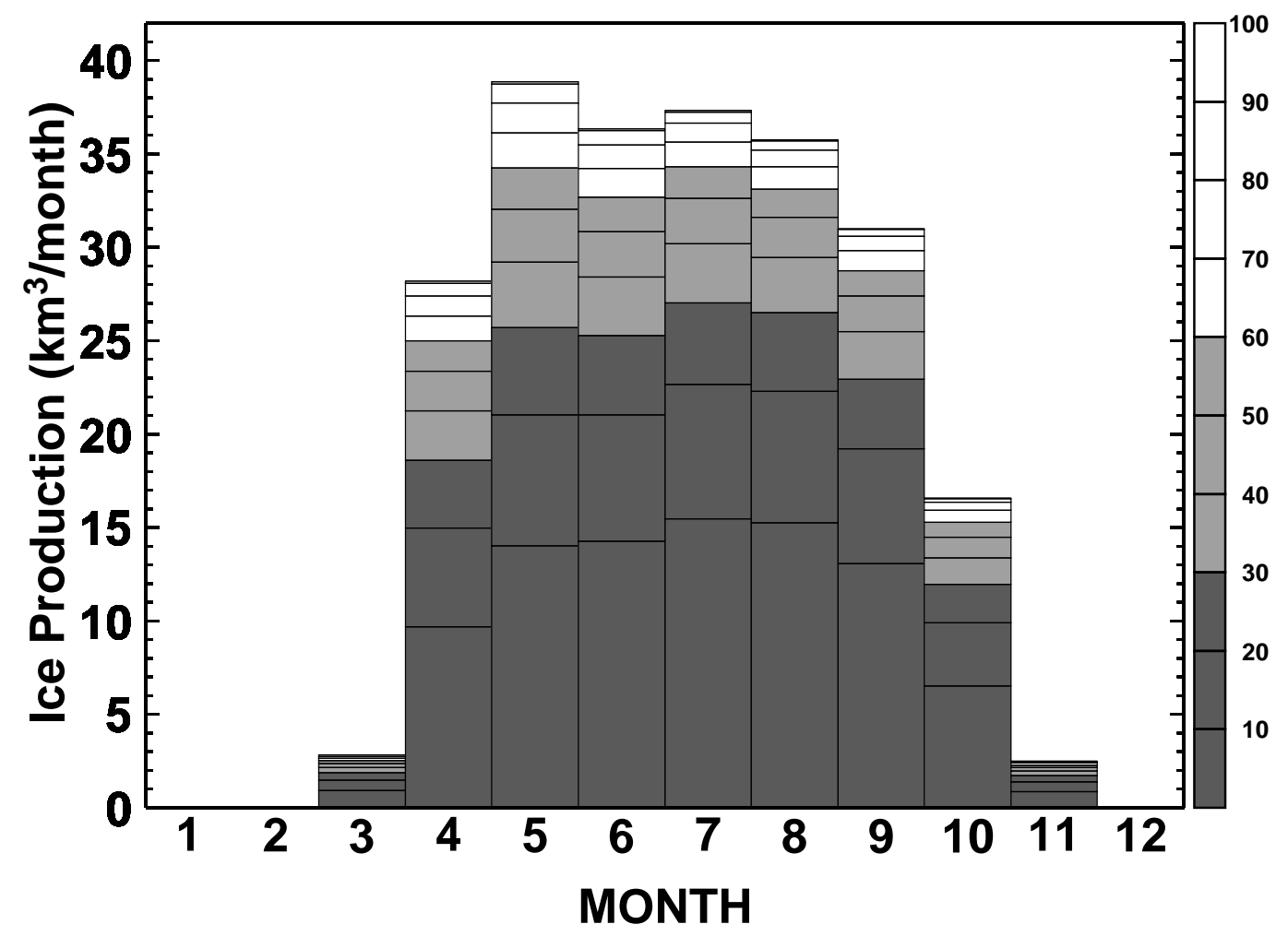

Figure 7: 

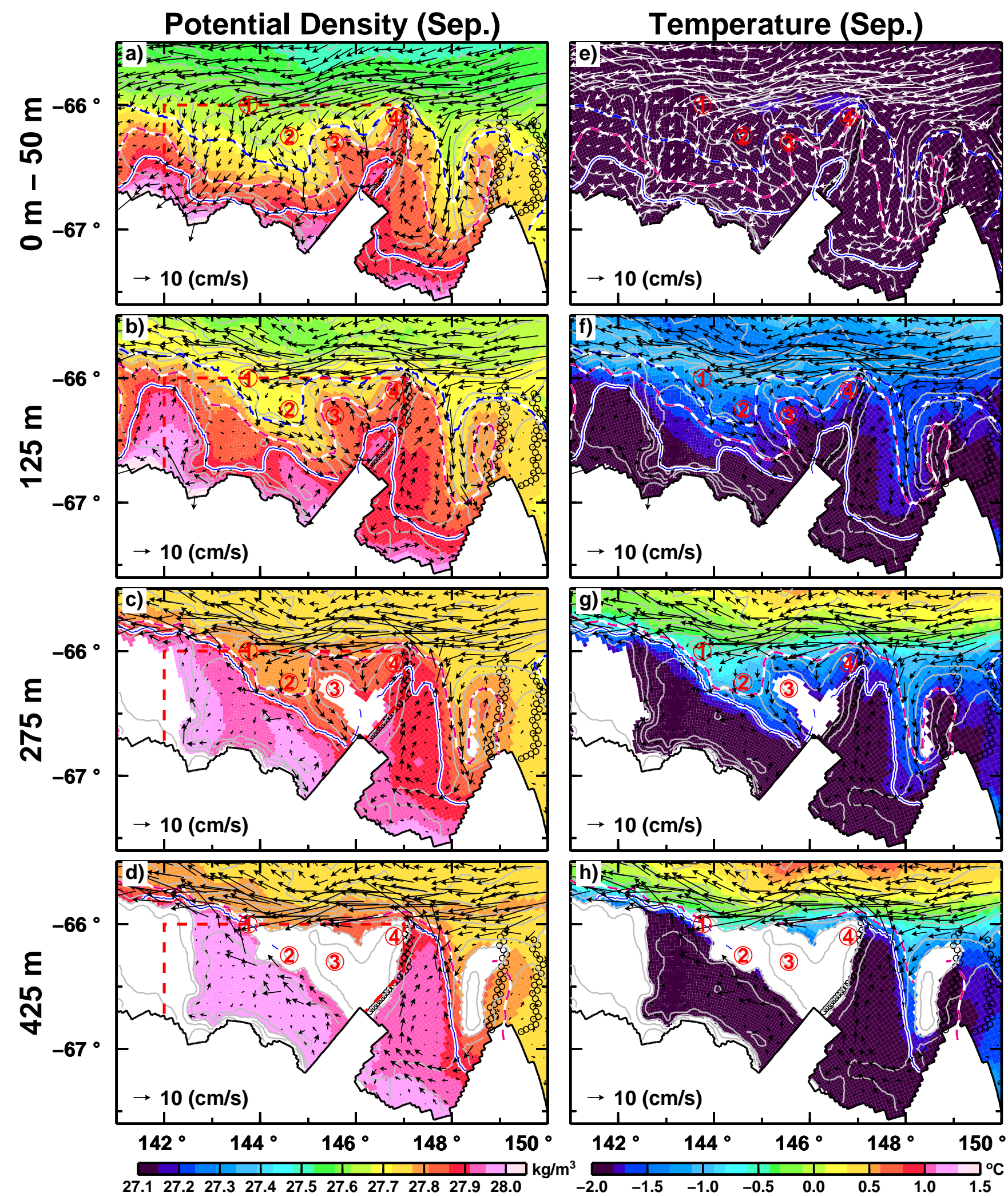

Figure 8: 

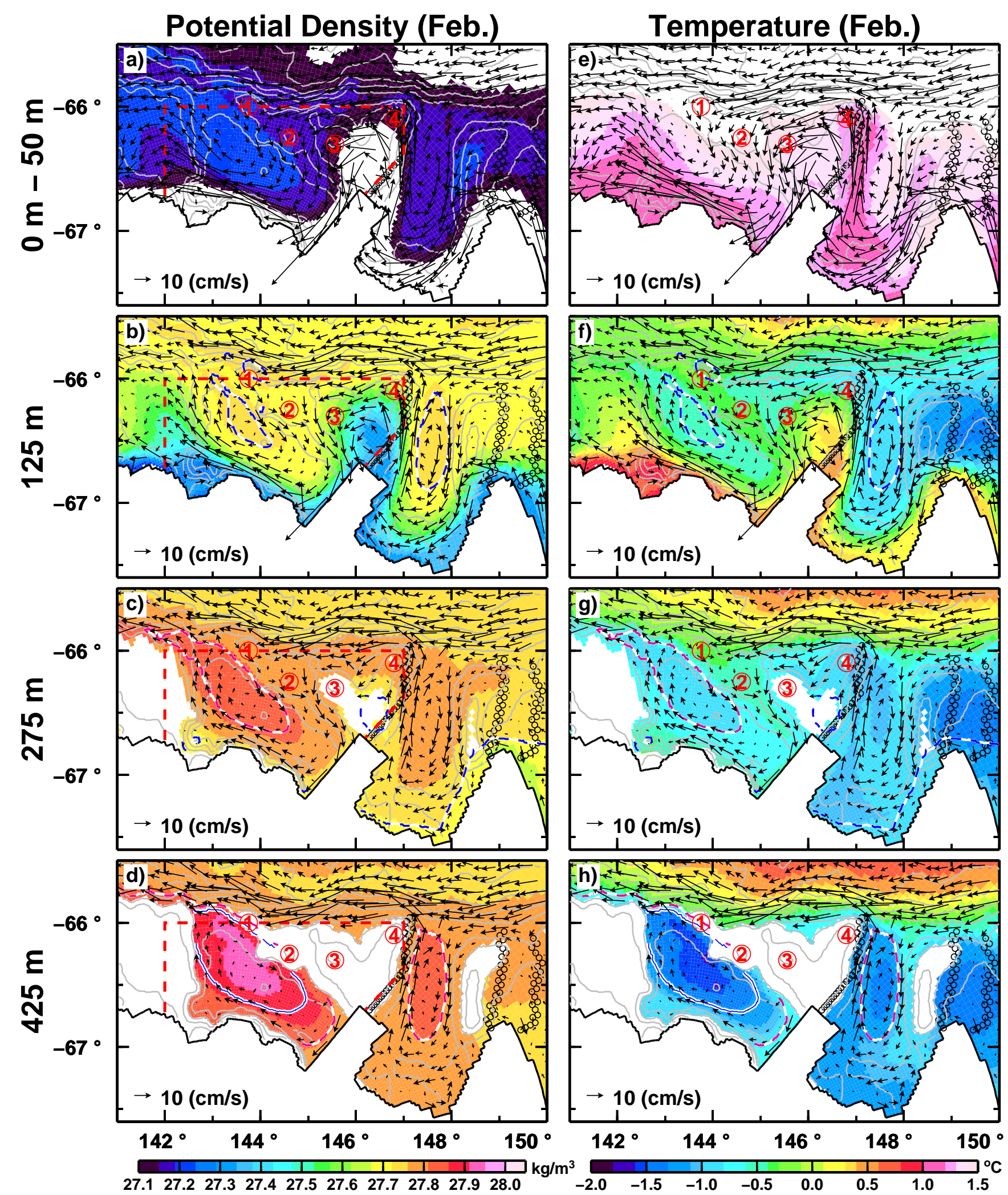

Figure 9: 


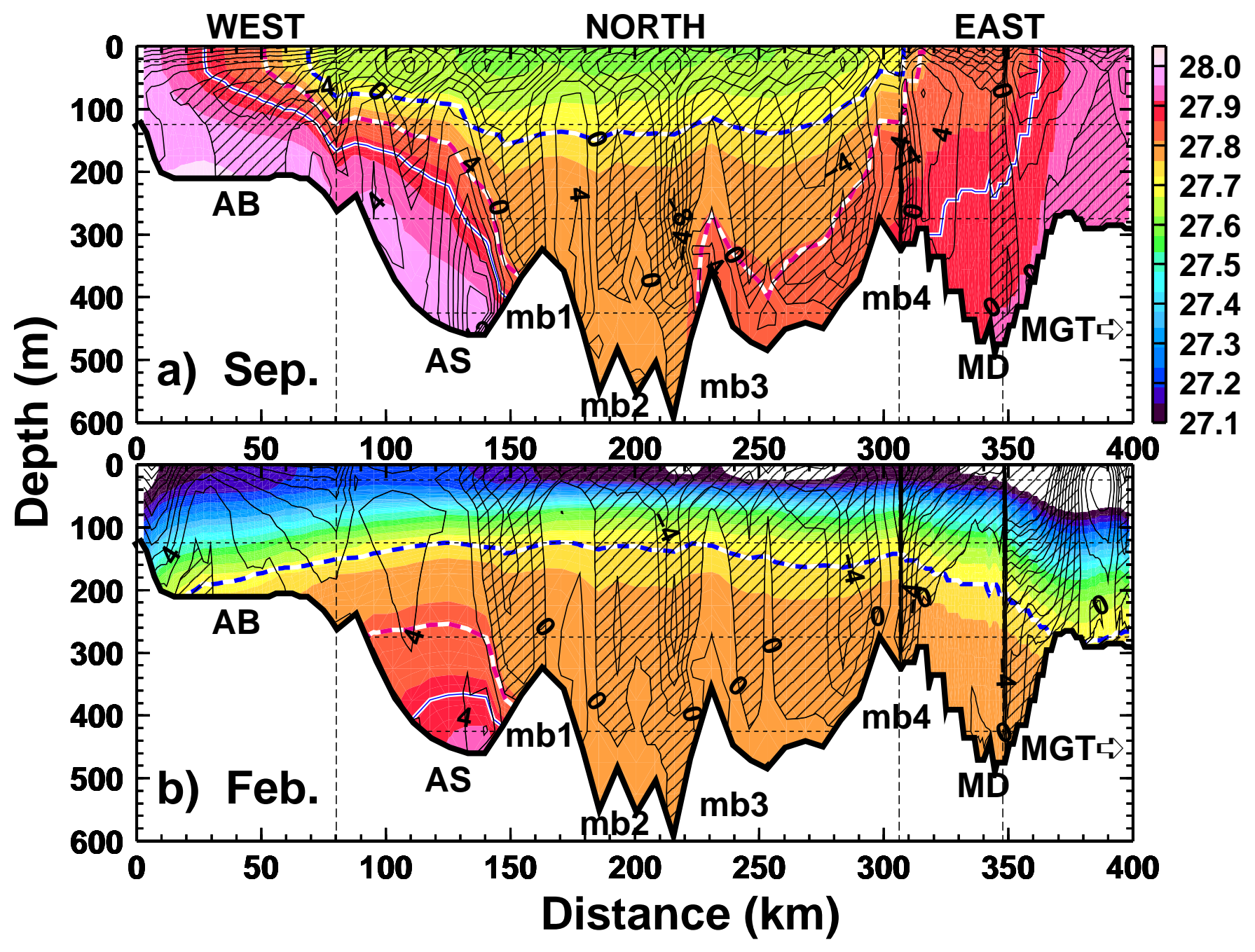

Figure 10: 

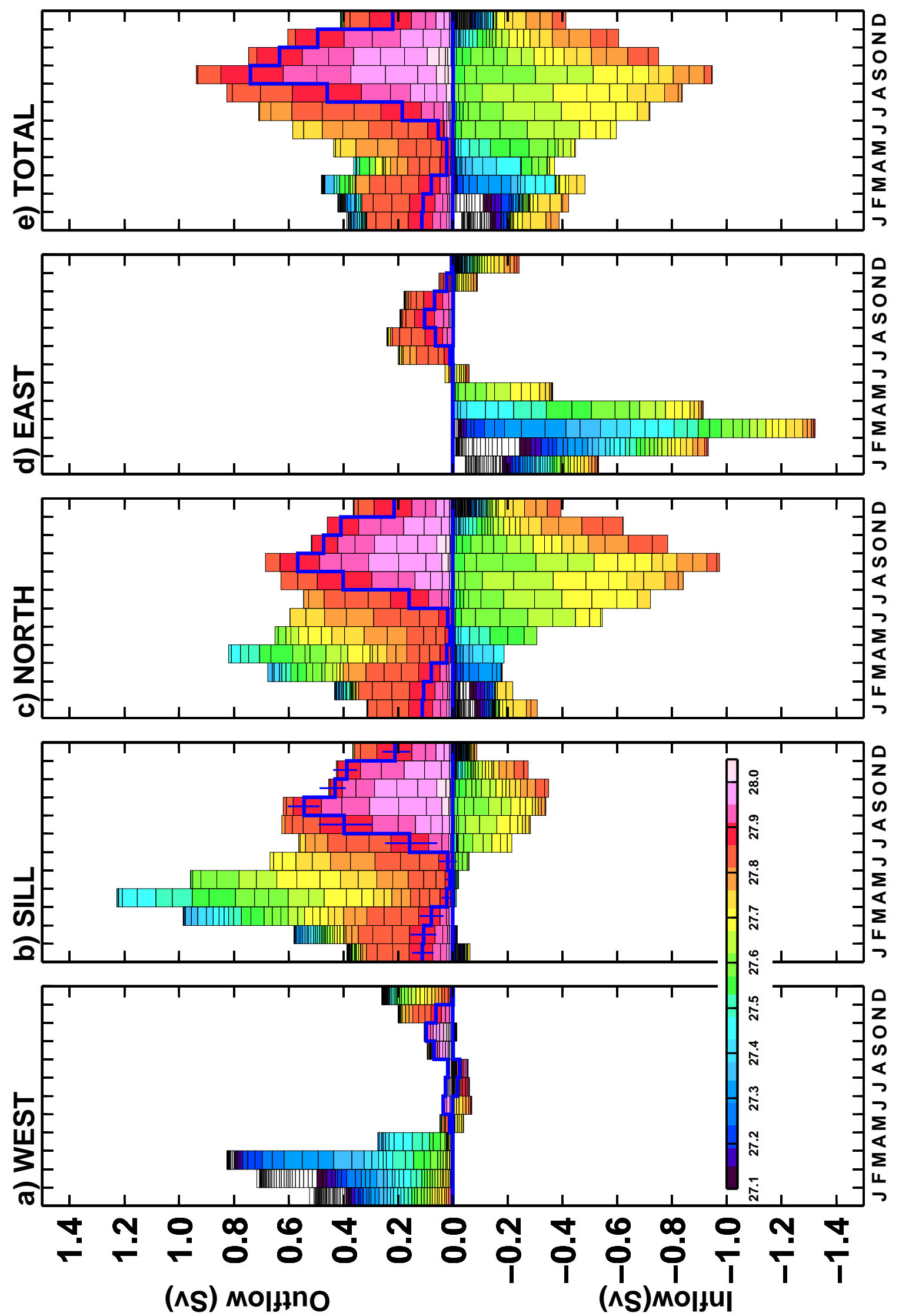

Figure 11: 


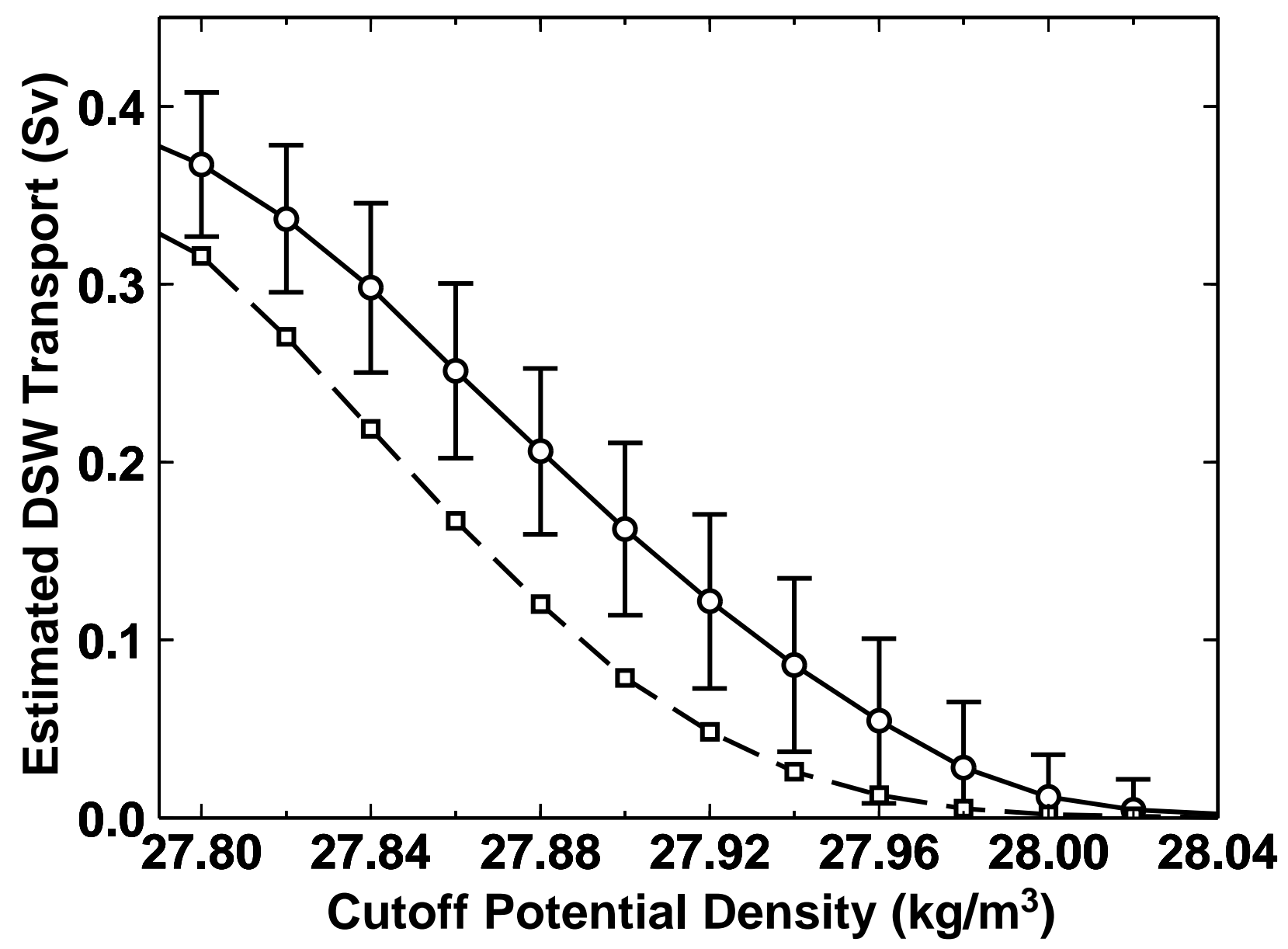

Figure 12: 
$\begin{array}{llllllllllllllll}34.2 & 34.4 & 34.6 & 34.8 & 35 & 34.2 & 34.4 & 34.6 & 34.8 & 35 & 34.2 & 34.4 & 34.6 & 34.8 & 35\end{array}$
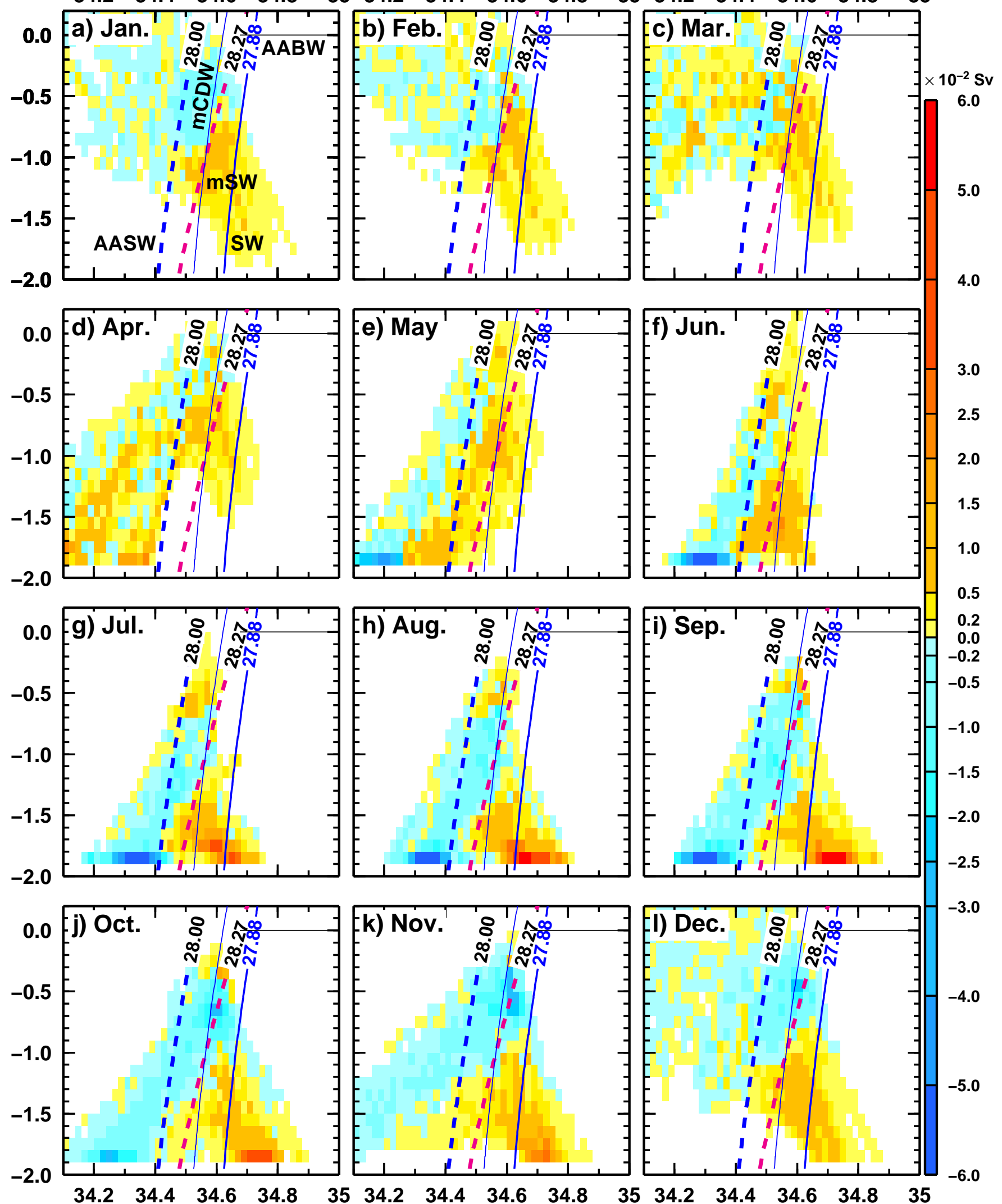

Figure 13: 


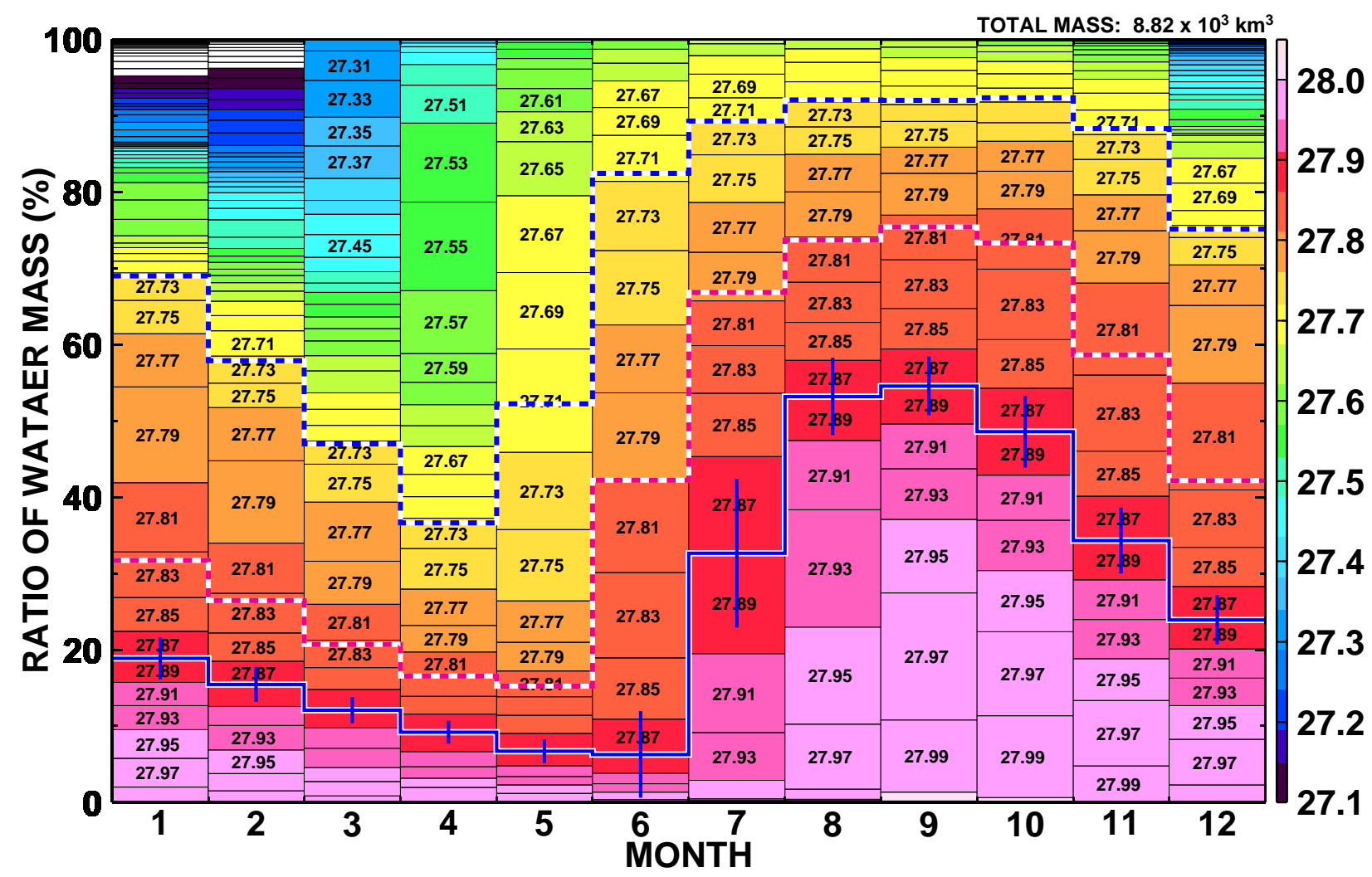

Figure 14: 
$\begin{array}{lllllllllllllll}34.2 & 34.4 & 34.6 & 34.8 & 35 & 34.2 & 34.4 & 34.6 & 34.8 & 35 & 34.2 & 34.4 & 34.6 & 34.8 & 35\end{array}$
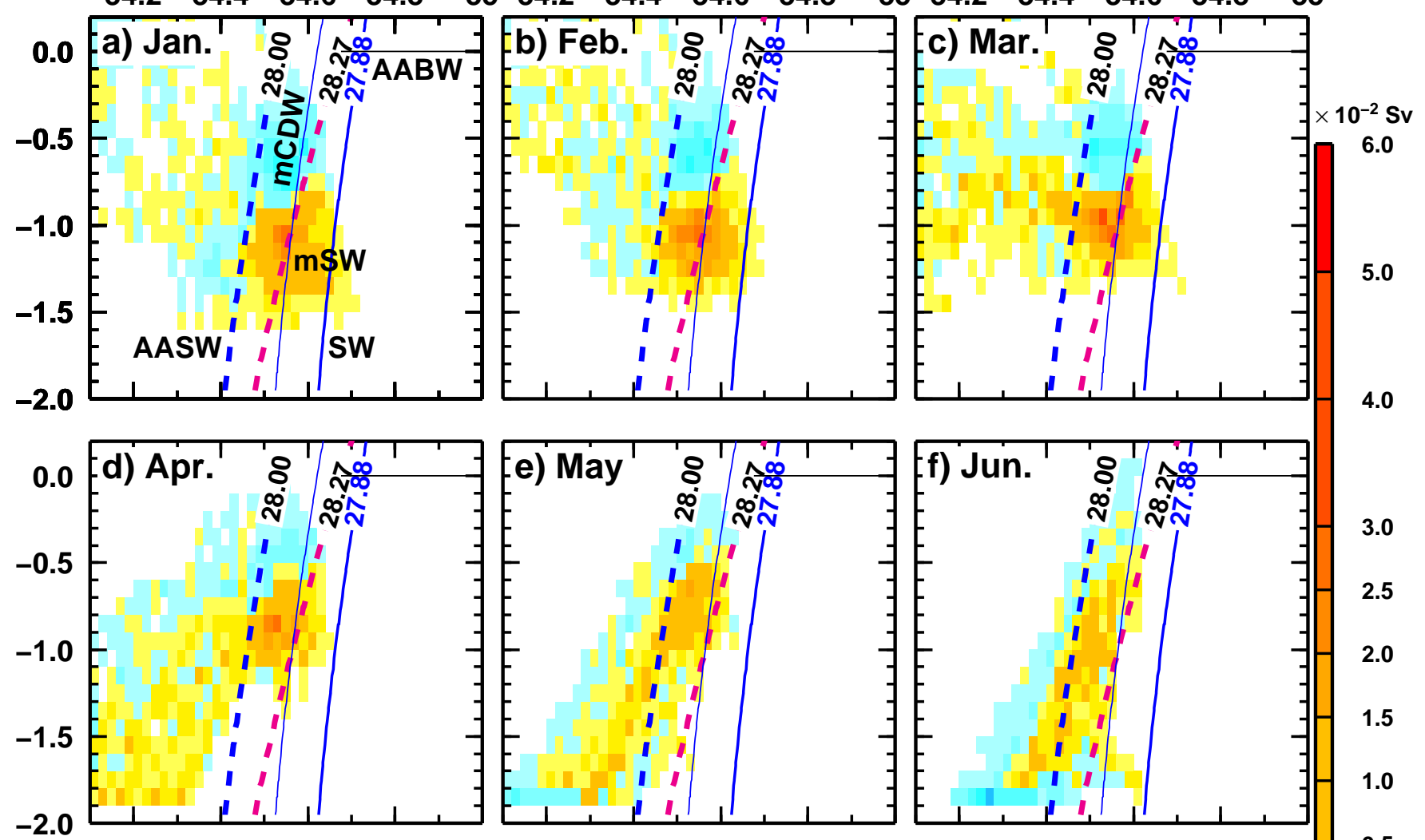

4.0
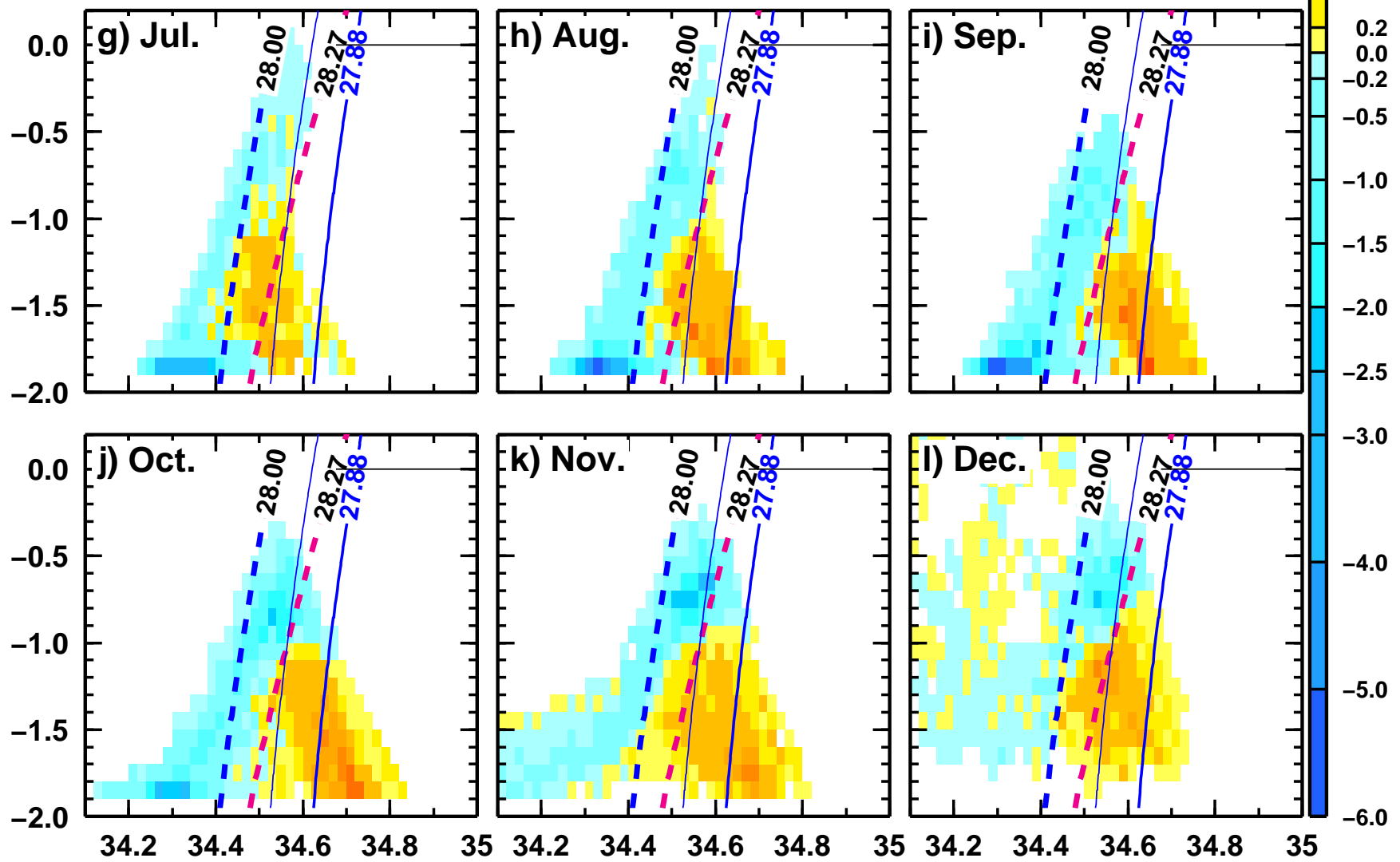

Figure 15: 
EXP1
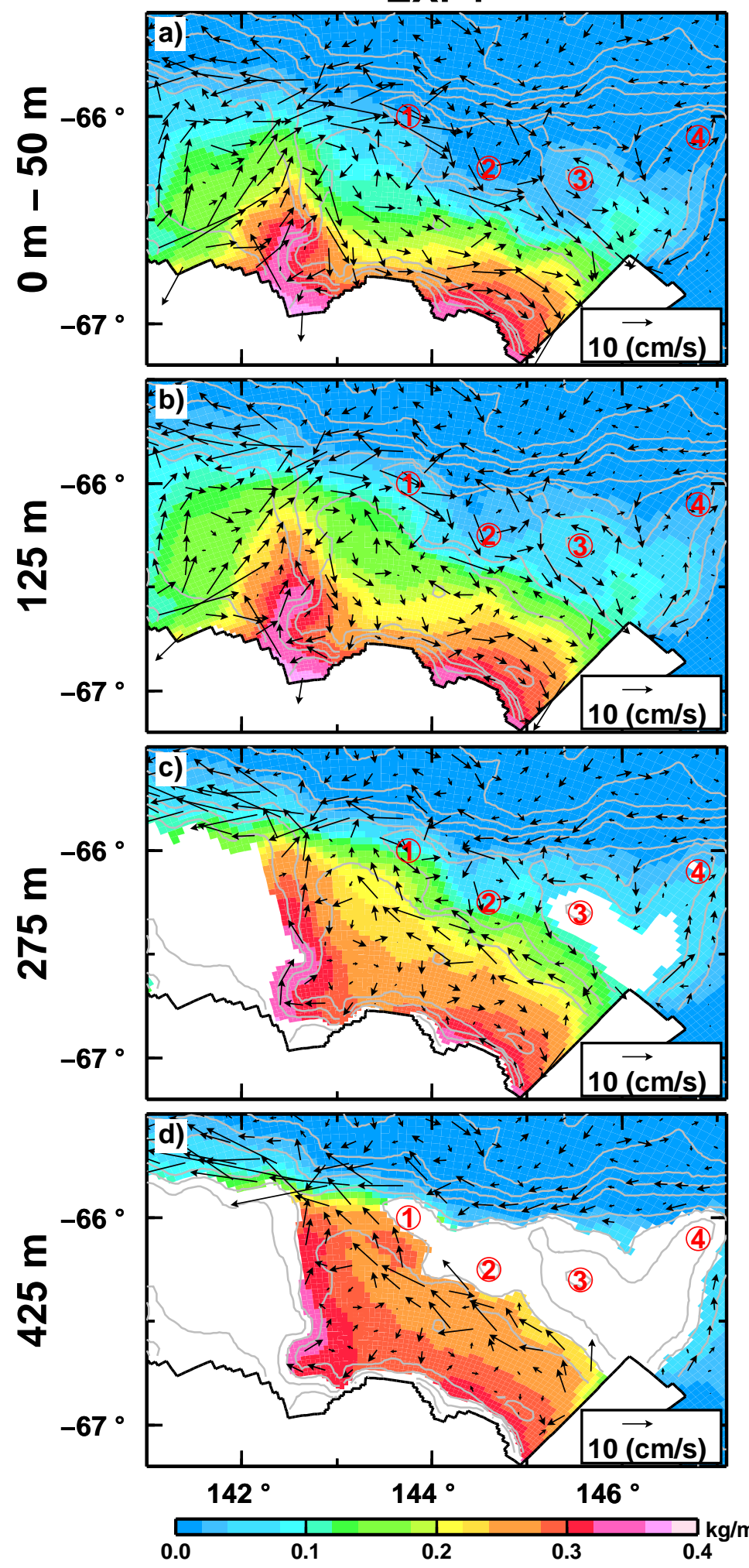

EXP4
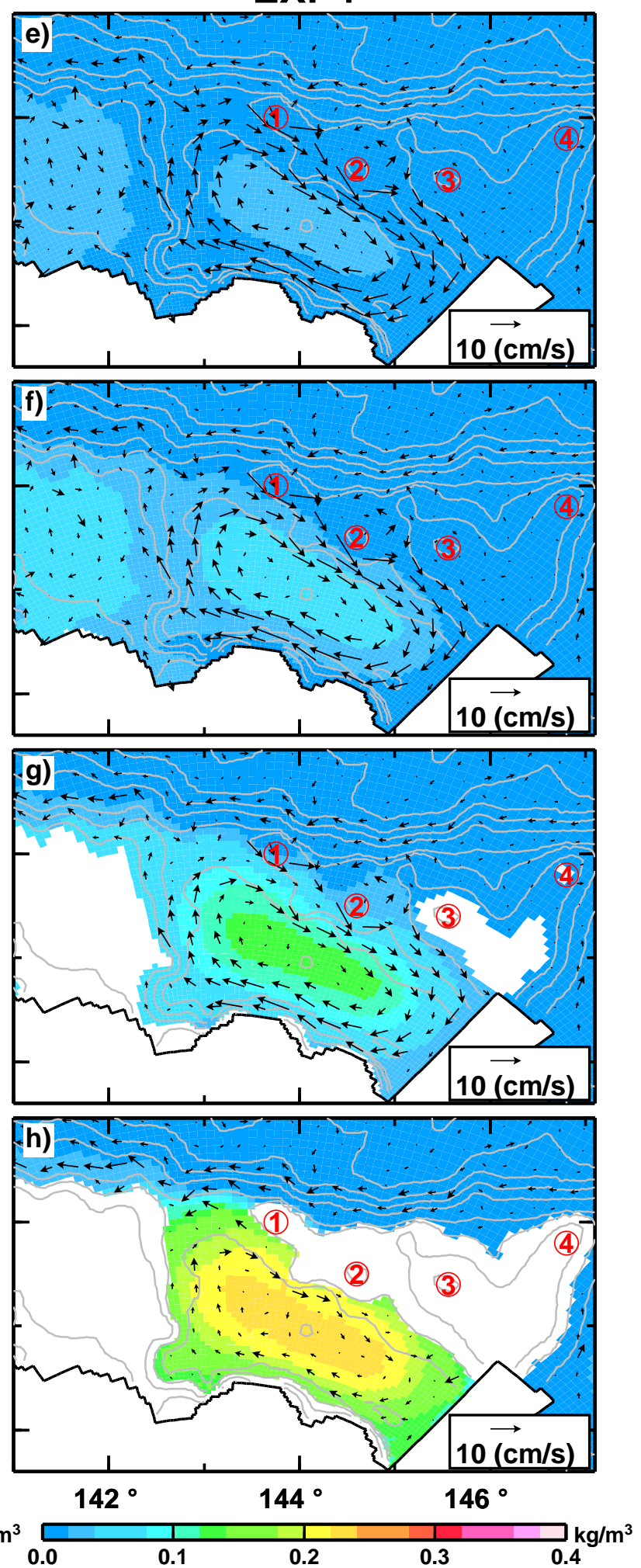

Figure 16: 